NBER WORKING PAPER SERIES

\title{
DO WORKING MEN REBEL? INSURGENCY AND UNEMPLOYMENT IN IRAQ AND THE PHILIPPINES
}

\author{
Eli Berman \\ Michael Callen \\ Joseph H. Felter \\ Jacob N. Shapiro \\ Working Paper 15547 \\ http://www.nber.org/papers/w15547 \\ NATIONAL BUREAU OF ECONOMIC RESEARCH \\ 1050 Massachusetts Avenue \\ Cambridge, MA 02138 \\ November 2009
}

We acknowledge the tremendously helpful comments received at the June 2009 Institute on Global Conflict and Cooperation conference on Governance, Development, and Political Violence, and at seminars at UC Berkley, UC Irvine, UCLA, UC San Diego, the University of Southern California, and the University of Ottawa.. L. Choon Wang, Josh Martin, Lindsay Heger and Luke N. Condra provided invaluable research assistance. Gordon Dahl, James Fearon, Esteban Klor, Daniele Paserman, Kris Ramsay, and our anonymous reviewers provided critical comments. We acknowledge grant \#2007-ST-061-000001 by the United States Department of Homeland Security through the National Center for Risk and Economic Analysis of Terrorism Events and grant \# FA9550-09-1-0314 by the United States Department of Defense through the Air Force Office of Scientific Research. The opinions, findings, and recommendations in this document are the authors' and do not reflect views of the United States Department of Homeland Security or Department of Defense. All mistakes are ours. Replication data are available on the authors websites and at http://jcr.sagepub.com/. The views expressed herein are those of the author(s) and do not necessarily reflect the views of the National Bureau of Economic Research.

NBER working papers are circulated for discussion and comment purposes. They have not been peerreviewed or been subject to the review by the NBER Board of Directors that accompanies official NBER publications.

(C) 2009 by Eli Berman, Michael Callen, Joseph H. Felter, and Jacob N. Shapiro. All rights reserved. Short sections of text, not to exceed two paragraphs, may be quoted without explicit permission provided that full credit, including (C) notice, is given to the source. 
Do Working Men Rebel? Insurgency and Unemployment in Iraq and the Philippines

Eli Berman, Michael Callen, Joseph H. Felter, and Jacob N. Shapiro

NBER Working Paper No. 15547

November 2009, Revised December 2010

JEL No. F51,F52,H4,H56,J6,O12,O53

\begin{abstract}
$\underline{\text { ABSTRACT }}$
Most aid spending by governments seeking to rebuild social and political order is based on an opportunity-cost theory of distracting potential recruits. The logic is that gainfully employed young men are less likely to participate in political violence, implying a positive correlation between unemployment and violence in locations with active insurgencies. We test that prediction in Afghanistan, Iraq and the Philippines, using survey data on unemployment and two newly-available measures of insurgency: (1) attacks against government and allied forces; and (2) violence that kills civilians. Contrary to the opportunity-cost theory, the data emphatically reject a positive correlation between unemployment and attacks against government and allied forces $(\mathrm{p}<.05 \%)$. There is no significant relationship between unemployment and the rate of insurgent attacks that kill civilians. We identify several potential explanations, introducing the notion of insurgent precision to adjudicate between the possibilities that predation on the one hand, and security measures and information costs on the other, account for the negative correlation between unemployment and violence in these three conflicts.
\end{abstract}

Eli Berman

Department of Economics, 508

University of California, San Diego

9500 Gilman Drive

La Jolla, CA 92093

and NBER

elib@ucsd.edu

Michael Callen

Department of Economics, 508

University of California San Diego

9500 Gilman Dr.

La Jolla, CA 92093

mjcallen@ucsd.edu
Joseph H. Felter

Hoover Institution

434 Galvez Mall

Stanford University

Stanford, CA 94305-6010

felter@hoover.stanford.edu

Jacob N. Shapiro

Woodrow Wilson School of Public Policy

and International Affairs

Princeton University

Robertson Hall

Princeton, NJ 08544-1013

jns@princeton.edu 


\section{Introduction}

The vast majority of aid money spent to reduce political violence is motivated by an opportunity-cost theory of distracting recruits. Two causal logics underlie this theory (United States Army 2006). The most commonly cited is that gainfully employed young men are less likely to participate in insurgent violence ${ }^{1}$. A slightly less prominent argument is that unemployment creates grievances, generating support for insurgent violence (Brainard and Chollet 2007, 3). This support could lead to more violence directly — through more recruits or enhanced fundraising — or indirectly — by reducing the willingness of a population to share information with counter insurgents. Whichever causal pathway is posited, the testable implication is the same: a positive correlation between unemployment and insurgent violence.

The opportunity-cost approach is generally based upon a number of often implicit assumptions about the production of insurgent violence. Some of these include:

- Participation in insurgency is a full-time occupation, in the sense that individuals cannot be legitimately employed and active insurgents at the same time.

- Insurgency is a low-skill occupation so that creating jobs for the marginal unemployed reduces the pool of potential recruits.

- The supply of labor is a binding constraint on insurgent organizations. Each of these assumptions is questionable in some contexts, suggesting first that empirical testing is warranted, and second, that the relationship between unemployment and insurgency may be more complex than is commonly assumed.

Other causal channels predict a negative correlation between unemployment and violence. Suppose, for example, that the main constraint on the production of violence is the extent to which non-combatants share information about insurgents with the government (Kalyvas, 2006; Berman, Shapiro and Felter, 2008). If counterinsurgents spend money to buy intelligence — as they routinely do — then as the local employment

\footnotetext{
${ }^{1}$ General Chiarelli, the U.S. Army Commander of Multinational Forces in Iraq, made this argument in a press briefing, December 8, 2006.
} 
picture worsens and household incomes drop, the marginal dollar spent to buy information will go further and violence will fall. Alternatively, suppose that security efforts - establishing checkpoints and the like-reduce violence but also increase unemployment by impeding the movement of goods and services (Hendawi 2008). That would imply a negative correlation between unemployment and violence. Or, fighting a perceived occupying force might be something people do out of belief in the cause, but can do only once their basic needs are satisfied. If insurgency is a normal good" in this narrow sense, then an improved economic situation could lead to greater levels of participation and hence greater violence so that reduced unemployment causes more violence.

We investigate the relationship between unemployment and political violence using panel data on local unemployment and insurgent violence in three countries: Afghanistan, Iraq, and the Philippines. ${ }^{2}$ These countries vary greatly both in geography and in the nature and intensity of the insurgencies they face. Yet they yield broadly similar results.

The data rule out a positive correlation between unemployment and violence for all three countries: if there is an opportunity cost effect, it is not dominant in any of them. Using micro-data from three countries provides plenty of inferential leverage. Assuming that the internal relationships between violence and unemployment within these countries are independent - a reasonable assumption given their geographic spread and the different time periods observed in each — then combining our results across countries allows us to reject the null hypothesis of a positive correlation at the $99.95 \%$ confidence level.

Why is the correlation of unemployment and violence generally negative? Existing data do not allow us to fully adjudicate between possible reasons, but we offer evidence that it is due to the relationship between local economic conditions and

\footnotetext{
${ }^{2}$ Our data are based labor force surveys and three newly-available datasets that include two sub-national measures of insurgency: (1) attacks against government and allied forces; and (2) violence that kills civilians.
} 
counterinsurgents' efforts to combat violence. Our findings are consistent with two hypotheses concerning counterinsurgency: (1) as local economic conditions deteriorate, government forces and their allies are able to buy more intelligence on insurgents (i.e., the price of information falls); and (2) actions taken to enhance security—establishing checkpoints, building walls, and the like — damage the economy.

The remainder of this paper describes our effort to study the relationship between unemployment and insurgent violence in Afghanistan, Iraq, and the Philippines. First, we briefly review the existing literature. We then lay out a theoretical framework -including some alternatives, describe our data, report estimation results, and conclude.

\section{Literature Survey}

Three major theoretical arguments link unemployment and violence at the local level. The first is the opportunity-cost approach which first surfaces in Becker's theory of crime (Becker, 1968). Grossman (1991) applies it to rebels' time-allocation, predicting that as opportunities for potential rebels to work in legitimate occupations improve, the amount of time they will provide to insurgency declines.

The opportunity-cost approach is incorporated in Fearon's (2008) model that predicts insurgent violence will increase in income inequality as relatively poor rebels see more to gain from expropriating resources from the relatively rich. This model links opportunity costs to a second theoretical mechanism - appropriation, or rent capture - the idea that the greater the economic gains associated with controlling an area, the greater the effort rebels will invest in violent capture. Dube and Vargas (2008), for example, report evidence that violence increases in oil-rich areas of rural Colombia when the price of oil increases. Similarly, Hidalgo et al (2010) provide empirical evidence that economic shocks drive the rural poor in Brazil to invade large landholdings and that this effect is especially pronounced in areas of high land inequality and in areas with fixed-rent tenurial arrangements, which do not provide peasants insurance against income shocks. Blattman and Miguel (2009) provide a general survey. 
A third major theoretical argument is the hearts-and-minds approach, which states that the key predictor of violence is the attitude of the population towards the government. That attitude in turn predicts whether insurgents can survive to conduct attacks against a militarily superior foe. This strain of thinking has been most prominent among practitioners of insurgency and counterinsurgency. Mao Tse-Tung famously argued the people are the sea in which rebels must swim" (Mao, 1937).

Counterinsurgency theorists from the post-Colonial wars relied on similar arguments about the criticality of the population's attitudes ${ }^{3}$, as did the Iraq/Afghanistan cohort of Western counterinsurgents. ${ }^{4}$ Importantly, this literature stresses that it is not the ability to recruit combatants that constrains insurgents, but rather the ability to induce noncombatants to withhold information from counterinsurgents. Akerloff and Yellen (1994) present an analytical statement of this approach, arguing that excessive punishment will fail to deter urban street gangs if the community responds by withholding information police need to catch gang members. Evidence from captured internal documents of Al Qaeda in Iraq indicates analogous orders to avoid killing noncombatants (Combating Terrorism Center, 2006). ${ }^{5}$ A Taliban code of conduct released in the summer of 2009 contains explicit directives to - bing the hearts of civilian Muslims closer to them...." and to avoid civilian casualties. ${ }^{6}$ Berman, Shapiro, and Felter (2008) apply hearts and minds" logic to analyze the response of violence to reconstruction and social service

\footnotetext{
${ }^{3}$ This view is largely based on the British experience in Malaya, the French in Algeria and the U.S. in Vietnam. It is explained in Triquier (1961), Taber (1965), Galula (1964), Clutterbuck (1966), Thompson (1966), Kitson (1971), and Popkin (1979).

${ }^{4}$ Articles by practitioners in this vein include Sepp (2005), Petraeus (2006), Cassidy (2006), and McMaster (2008). This is distinct from Berman and Laitin (2008), and Berman (2009), who argue certain rebel clubs do not share information with noncombatants, and are thus unaffected by actions of noncombatants. Economic development and improved governance still play a role in countering these clubs, though, as their social-service providing organizational bases are vulnerable to competition. 5 Stop the killing of people unless they are spying, military, or police officers. If we continue using the same method, people will start fighting us in the streets." From, Instructions to Abu-Usamah" from the collection - Captured Zarqawi Network Letters from Iraq" posted April 20 2006, www.ctc.usma.edu/harmony/harmony.asp , accessed June 52010.

${ }^{6}$ Al Jazeera (2009), http://english.aljazeera.net/news/asia/2009/07/200972775236982270.html, accessed June 52010.
} 
provision programs in Iraq, testing the logic that these programs cause noncombatants to favor the government side, inducing them to share information with counterinsurgents.

Evidence generally supports opportunity-cost theory at the sub-national level with respect to crime. Studies show that in the United States crime rates increase as wages in the legal economy fall and as unemployment rises (Grogger, 1998; Gould et al 2002; Raphael and Winter-Ebmer, 2001). A similar pattern has been observed with respect to insurgency in rural Columbia where increases in prices of agricultural commodities predict reduced insurgent violence (Dube and Vargas, 2008) and with respect to uprisings in Brazil where economic shocks drive land invasions by the rural poor (Hidalgo et al, 2010). These findings are consistent with cross-country evidence that low GDP/capita predicts civil wars (Collier and Hoeffler, 1998; Fearon and Laitin, 2003); that correlation holds even when using rainfall to identify exogenous variation in GDP/capita (Miguel et al, 2004). A notable exception is Benmelech, Berrebi, and Klor (2010), who-consistent with our results for Afghanistan, Iraq, and the Philippines below-find that unemployment and the incidence of suicide attacks in Palestine are negatively correlated, even after including fixed effects and a rich set of covariates.

Little formal quantitative research has been reported which tests opportunity cost theory in the context of political violence, or that tests hearts-and-minds theory, though the literature cited above is rife with supportive anecdotal evidence. This is unfortunate, as determining which mechanism is dominant- hearts and minds or opportunity costsis critical to properly designing economic aid programs in efforts to rebuild social and political order. 


\section{Theoretical Framework}

The opportunity cost approach is a theory of rebel recruitment and retention along the lines of Becker's (1968) theory of crime. Imagine a potential insurgent choosing between work at wage $w$, and insurgency. Many factors might influence the decision of those individuals, including commitment to a cause, risk aversion, attitudes towards violence, etc., all of which would influence the threshold market wage, $w^{*}$, above which they would prefer work to insurgency. Let $F\left(w^{*}\right)$ be the cumulative distribution of threshold wages across both potential and current insurgents, and let $N$ be the number of such individuals. For simplicity assume a single wage rate, w, in the economy. Then N(1$F(w))$ is the number of insurgents, a decreasing function of wages in the legitimate economy. Assuming that variation in unemployment is due to variation in labor demand, a negative correlation between wage rates and unemployment rates would yield a positive correlation between unemployment and the number of insurgents.

In this fairly general version of the opportunity cost theory, insurgents are drawn not only from among the unemployed, but also from among individuals in low wage employment or who are out of the labor force. One could easily generalize to a model in which insurgency is a not a full time job by adding an intensive (hours) margin, in which insurgent hours would also increase with market wages, and decrease with unemployment. Even among individuals who are currently out of the labor force the expectation of a high wage in some future employment, which would be precluded by being caught engaging in insurgency would yield the same insurgency-reducing effect of high wages. Overall, these complementary mechanisms all yield the same overall prediction of a positive correlation of unemployment and the number of insurgents.

We do not directly observe the size of the insurgent force, only the amount of violence. Does a larger insurgent force imply more violence? For very small insurgent forces that must be true, but the relationship could turn out to be non-monotonic. If an insurgency became strong enough in numbers, it may reach a point at which more insurgents may induce the government (and/or its allies) to stop contesting the space, yielding less violence and much less measured violence (as measurement generally 
requires some degree of presence, with the notable exception of raids and air strikes). ${ }^{7}$ For a full analysis of the extent to which space is contested in a Hearts and Minds" counterinsurgency, see Berman, Shapiro and Felter (2008). They show that under fairly general conditions optimal effort by counterinsurgents increases monotonically with insurgent strength until the extreme case of uncontested regions is reached. Of the three conflicts we examine, the Afghan case is the only one in which there was substantial uncontested space. We treat this in our empirical analysis by separately examining the Pashtun majority regions which contain the areas that went uncontested because of a combination of insurgent strength and low Afghan and NATO troop levels (Rhode and Sanger 2007).

To summarize in terms of an estimating equation, across regions $r=1 \ldots R$, an opportunity cost theory predicts that the correlation between violence, $v$, and unemployment rates, $u$, will be positive, except if the region is uncontested, in which case the correlation should be zero (since the amount of violence is unrelated to the size of the insurgent force).

$$
v_{r}=\alpha+\beta u_{r}+\varepsilon_{r} .
$$

The first thing to note about this equation is that if violence increases unemployment by reducing access to markets or depressing investment, then an estimate of $\beta$ will be biased upward, exaggerating the true opportunity cost effect. Alternatively, that coefficient could be biased in a negative direction — and in fact the estimated correlation between unemployment and violence could be negative-if rent capture, security measures, or information cost mechanisms are in play. While we do not observe those directly, it is useful to examine the implications for a regression involving observables. We examine those ideas in turn.

\footnotetext{
${ }^{7}$ Kalyvas (2006) offers the strongest version of this argument. An alternative possibility is Fearon's (2008) suggestion that the insurgency could reach a size where additional members create more detection risk for the organization, leading to decreasing levels of realized violence.
} 
Rent capture, or predation, is the idea that violence is directed at the expropriation of economic rents, in the absence of some nonviolent means of dispute adjudication. Economic rents would then be an omitted variable with a positive coefficient in (1), plausibly having a negative correlation with unemployment - as economic activity is unemployment reducing. That would imply a negative bias on our estimated coefficient on unemployment, which, if rent capture dominated the opportunity costs mechanism, could make it negative. If insurgency were a normal good, the bias and testable implications would be the same as those of rent capture.

Security measures provide a second avenue relating unemployment and violence. Successful security measures reduce violence by definition. At the same time, roadblocks, curfews, barriers, spot inspections and other efforts to control the movement of goods and people might reduce economic activity, even accounting for the countervailing increase in economic activity due to improved security of people and property. That was the case in the West Bank and Gaza in the 1990s, for example, where the benefits of security measures imposed through movement and access restrictions accrued mostly to Israelis, while the economic costs were borne by Palestinians, generating very high unemployment rates (Fischer et. al. 2001; Kanaan 1998). Kanaan emphasizes that even in a very agricultural economy, uncertainty about the duration of a trip to market can severely depress investment, causing economic damage. Security measures, especially the building of large blast walls, also had widely-discussed negative repercussions for the flow of goods, services, and people in Baghdad in 2007 (Crain 2007). If security measures are positively correlated with unemployment then they imply a negative bias on an estimate of $\beta$ in equation (1), which, if damage due to security measure dominates the opportunity cost mechanism, could make the estimate negative.

Finally, information costs might decrease when unemployment rises, allowing for violence reduction through a separate security mechanism - the market for information, or tips. Counterinsurgents routinely use rewards to buy information on insurgents. The British government in Malaysia, for example, paid informants on a sliding pay scale based on the organizational role of the people killed or captured as a result of tips, 
informing on platoon commanders paid more than informing on rank-and-file soldiers and so on. ${ }^{8}$ The U.S. Central Command REWARDS program, for example, was set up to facilitate the capture of wanted persons or weapons" among other purposes (MultiNational Corps Iraq 2009, D-3). High unemployment is a symptom of low income, and the lower is income, the more information counterinsurgents can purchase (either in cash or in kind) with a given budget. ${ }^{9}$ In other words, high unemployment should indicate a low price per tip. If those tips allow reductions in violence, and low tip prices are negatively correlated with the unemployment rate, then the estimate of $\beta$ in equation (1) would again be biased downward, and could be negative if this information cost mechanism dominates the opportunity cost effect.

All three of these alternatives predict a negative bias in the relationship between unemployment and insurgent violence. Anticipating a consistently negative coefficient we need a way to distinguishing between explanations. Security and information mechanisms share the characteristic that unemployment proxies for factors that limit the operational effectiveness of insurgents. To measure that effectiveness we calculate insurgent precision, the proportion of attacks on coalition forces that kill no civilians.

Here it is important to bear in mind that insurgents generally aim to avoid killing civilians. That is a direct implication of Hearts and Minds" theory, in which noncombatants control operationally crucial information. In the literature survey we

\footnotetext{
${ }^{8}$ Formally the British paid insurgents to surrender with established payments by position. Informants who provided information that led to the capture or killing of insurgents earned 75\% of those individuals' surrender values (Long 2006, 48 citing Komer 1972, 72-74).

${ }^{9}$ For a colorful summary of US activity buying tips in Afghanistan and elsewhere, see Joby Warrick -EIA buys Afghan chief"s loyalty with Viagra," in the Washington Post, 26 December 2008. In their efforts to win over notoriously fickle warlords and chieftains, the officials say, the agency's operatives have used a variety of personal services. These include pocket knives and tools, medicine or surgeries for ailing family members, toys and school equipment, tooth extractions, travel visas and, occasionally, pharmaceutical enhancements for aging patriarchs with slumping libidos, the [U.S. intelligence] officials said."
} 
provided a few examples from captured documents. One of those, the Taliban code of conduct (reportedly approved by the Mullah Omar) is quite explicit on this matter:

"Governors, district chiefs and line commanders and every member of the Mujahideen must do their best to avoid civilian deaths, civilian injuries and damage to civilian property. Great care must be taken....... Suicide attacks should only be used on high and important targets. A brave son of Islam should not be used for lower and useless targets. The utmost effort should be made to avoid civilian casualties." 10

These clear admonitions against civilian casualties imply that our insurgent precision measure is a reasonable proxy for the ease with which insurgents can attack.

Both the security effect and information cost mechanisms predict a negative relationship between unemployment and insurgent precision while the predation mechanism has no firm prediction. Both security and information effects should be strongest in more densely populated areas where the risk of killing civilians in any attack is greater, and hence the negative correlation between unemployment and insurgent precision should be strongest in densely populated areas.

In terms of an estimating equation, we have

$$
p_{r, t}=\mu+\pi u_{r, t}+\delta d_{r, t}+\theta u_{r, t} d_{r, t}+v_{r, t}
$$

where $p$ is insurgent precision, $d$ is population density, $u d$ is the interaction of unemployment and population density, with the subscripts indexing by region and time. The shared predictions of both the security measures mechanism and the information cost mechanism are that: precision and unemployment (proxying for improved security and/or low information costs) will be negatively correlated in the simple regression, equation (1); and the coefficient $\theta$ will be negative in equation (2), as high unemployment (again, as a proxy) reduces precision more in regions with

${ }^{10}$ Al Jazeera (2009), http://english.aljazeera.net/news/asia/2009/07/200972775236982270.html, accessed June 52010 . 
dense populations. Unfortunately we are unable to distinguishing between the security and information mechanisms using the data we have in hand, and must leave that investigation to future work. 


\section{Data}

We study the relationship between unemployment and violence at the local level in Afghanistan, Iraq, and the Philippines. In all three countries countries we collected observations of these variables for the smallest geographical units for which reliable population and unemployment data were available, the district $(\mathrm{n}=398)$ in Afghanistan, the district $(\mathrm{n}=104)$ in Iraq, and the province $(\mathrm{n}=76)$ in the Philippines. ${ }^{11}$

Our key dependent variable is the intensity of insurgent activity measured as the rate of attacks per capita against government forces and their allies. We generate these measures by aggregating incident-level data and focus on the rate of incidents because tightly geo-located data on Coalition and insurgent casualties are not publicly available for Iraq or Afghanistan. To maintain comparability of our estimates across countries we use incident rates as our primary dependent variable.

For Iraq we use two data sources on violence. The first are data drawn from ssignificant activity' (SIGACT) reports submitted by Coalition forces. These capture a wide variety of information about - ...xecuted enemy attacks targeted against coalition, Iraqi Security Forces (ISF), civilians, Iraqi infrastructure and government organizations" (Government Accounting Office, 2007; Department of Defense, 2008). Unclassified data drawn from the Multi-National Forces Iraq SIGACTS III Database provide the location (to approximately 100 meters), date, and time of attack for incidents between February 2004 and July 2008. ${ }^{12}$ We filtered these data to exclude violence not directed at Coalition and Iraqi government targets leaving a data set of 148,546 incidents spanning February 2004 - December 2007.

The unclassified information from the SIGACT data do not measure the consequences of attacks, so we supplement them with data from Iraq Body Count (IBC),

\footnotetext{
${ }^{11}$ All data provided by the Empirical Studies of Conflict (ESOC) Project.

${ }^{12}$ The information provided in the unclassified SIGACT data are limited to the fact of and type of terrorist/ insurgent attacks (including improvised explosive devices [IEDs]) and the estimated date and location they occurred.
} 
which uses press reporting to identify incidents that kill non-combatants. The IBC data capture 13,335 incidents in which civilians were killed (that can be accurately geolocated). These incidents account for 49,391 civilian deaths. Each incident includes a reported target. We divide these killings into three categories, which will provide analytical leverage on the relationship between unemployment and violence:

1. Insurgent killings of civilians in the course of attacking Coalition or Iraqi government targets.

2. Coalition killings of civilians.

3. Sectarian killings, which includes all killing of civilians not falling in the other categories, capturing ethnic cleansing, reprisal killings, and the like. Insurgent precision is measured as the proportion of SIGACT attacks in a district/quarter that do not result in IBC insurgent-caused civilian casualties. That proportion averages $92.3 \%$, weighted by population.

The analogues to SIGACTS incidents in Afghanistan are reported in two databases, the Joint Operations - INTEL Information System (JOIIS) and the Combined Information Data Network Exchange (CIDNE); these differ because of different recording practices and definitions of incidents. JOIIS incidents reported are very broad, including counterinsurgency incidents, criminal events, economic events, enemy action, explosive hazards, friendly action, friendly fire, noncombatant events and -suspicious" events. A subset of these, designated AGE", are enemy actions and explosive hazard events. CIDNE events include small arms fire, prematurely detonated explosives, mine strikes, mines found and/or cleared, IED (improvised explosive devices) found and/or cleared, IED explosions, IED hoaxes, suicide attacks, and indirect fire events. As in Iraq, incidents have time and location fields. We aggregate to district-months to match unemployment data in six separate months spread over 2008 and 2009.

To generate data on insurgent attacks in the Philippines we coded unclassified details of over 22,245 individual internal security incidents reported by the Armed Forces of the Philippines from 1997-2006. These data were compiled from the original field reports of every operational incident reported during this period to the Armed Forces of 
the Philippines' Joint Operations Center by units conducting counterinsurgency and other internal security operations. Information coded from these reports include the date, location, and description of each incident, including the number of civilian casualties and who initiated the incident. ${ }^{13}$ Each incident was assigned a unique location identification number that allows it to be plotted at the village level.

The lack of fine-grained data on unemployment is the limiting factor in our analysis in all three countries. In Afghanistan we use five waves of the Afghan National Quarterly Assessment Report (ANQAR) household surveys, which we have from September 2008 through September 2009. ${ }^{14}$ In Iraq three surveys capture unemployment at the district level: the Iraq Living Conditions Survey (ILCS) which was fielded in March and April 2004, the 2005 World Food Program Food Security and Vulnerability Analysis in Iraq (June and July 2005), and the World Food Program Food Security and Vulnerability Analysis in Iraq (November and December 2007). In the Philippines we obtained provincial level unemployment rates based on the Republic of the Philippines Census Organization‘s quarterly Labor Force Survey (LFS) for 1997-2003 and 2006. ${ }^{15}$

To maximize the accuracy of our estimates we focus on periods when the data on unemployment are available. For Afghanistan we have between 363 and 365 (of the 398) Afghan districts for six separate months in 2008 and 2009. (The two dropped districts were lost because of unmatched district names.) For Iraq we have 297 observations: 99 districts over three quarters when surveys were in the field (Q1:04, Q2:05, Q4:07). ${ }^{16}$ For

${ }^{13}$ Data for other conflicts do not reliable count government-initiated incidents and so in our analysis we focus on insurgent-initiated incidents for the Philippines to maximize comparability.

${ }^{14}$ ANQAR survey waves were fielded as follows: Sept. 14-25, 2008; Dec. 23, 2008 - Jan 2, 2009; Feb. 25 - March 9, 2009; June 4-13, 2009; Sept. 2009.

${ }^{15}$ The quarterly labor force surveys were aggregated to the provincial level by the Philippine Human Development Network to obtain reliable province-level estimates. Summary statistics are from their 2005 and 2008 reports and include figures for 19972003 and 2006. Data available at http://hdn.org.ph/philippine-human-developmentreports/\#hdrs.

${ }^{16}$ Five districts in Kurdish regions were not surveyed. These districts suffered little to no insurgent violence 
the Philippines this approach yields 546 observations: 78 provinces over seven years during which we observe both unemployment and violence (1997-1999, 2001 - 2003, and 2006). Table 1 provides population-weighted summary statistics for incident counts and other key variables.

\section{[INSERT TABLE 1 ABOUT HERE.]}

Several facts stand out from Table 1. First, the insurgency in Iraq is substantially more intense than that in Afghanistan or the Philippines. When measured in incidents per thousand the civilian casualty rate is an order of magnitude higher in Iraq than in the Philippines. Second, provinces in the Philippines are larger than districts in Iraq, and much larger than those in Afghanistan. This means our estimates for the latter two countries allow more precise matching of incidents to unemployment and other demographic variables that may predict violence. In Iraq our proxy for the proportion Sunni in a district is the vote share of political parties associated with the Sunni denomination at the governorate level, which averages $21 \% .{ }^{17}$ In the Philippines we measure $5.4 \%$ of the population as Muslim, concentrated in the southern islands. In Afghanistan we measure the percent Pashtun (averaging 38.5\%), the proportion of males in a household (which may vary because of migration, and averages 52\%) and household size (which averages 9.6 persons).

\section{Estimation}

We seek to estimate the relationship between violence and unemployment in the equation (1), reproduced here with time subscripts and with a region specific fixed effect,

$$
\text { (1') } \quad v_{r, t}=\alpha_{r}+\beta u_{r, t}+\gamma_{t}+\varepsilon_{r, t}
$$

\footnotetext{
${ }^{17}$ Using district-level ethnicity measures created by combining maps with remote-sensing data on population does not effect the results.
} 
where $v$ measures the incidence of violence, $u$ is the unemployment rate, $r$ indicates region (districts in Iraq and Afghanistan, provinces in the Philippines), $\alpha_{r}$ are regionspecific fixed effects, and $\gamma_{t}$ are period effects. Bearing in mind that violence is likely to reduce employment (by discouraging investment, consumption and production) we will interpret our estimate of the best linear predictor, $\beta$, as an underestimate of the causal effect of unemployment on violence.

Table 2 reports regression analysis for Afghanistan, Iraq, and the Philippines. The dependent variable in all specifications is the number of attacks against government forces - a category that includes both Coalition and Iraqi government forces in the Iraqi SIGACTS data. The key independent variable is the unemployment rate in that district/quarter (Iraq and Afghanistan) or province/year (Philippines). In Table 2 we report linear regressions on the number of attacks per 1,000 population.

We control for time-invariant region-specific characteristics in two ways. First, since both conflicts have an ethnic component we employ ethnicity controls: the Sunni vote-share in the December 2005 election for Iraq, the Muslim population share for the Philippines and the Pashtun population share for Afghanistan. Second, we employ region fixed-effects which control for all time-invariant region-specific factors (including ethnicity measures). In all regressions we use time fixed-effects to control for secular trends and seasonality affecting the entire country. We also re-run the analysis in regions where the relationship may differ across regions. In Iraq we focus on Baghdad (where population density may constrain rebels and coalition forces - as we discuss below). For the Philippines we focus on provinces with more than five percent Muslim population as much of the insurgent violence during the period we study is driven by the secessionist movement in Mindanao that is organized around religious grievances; the main insurgent group is the Moro Islamic Liberation Front (MILF). In Afghanistan we report results separately for majority Pashtun areas, where violence is concentrated. As a robustness check, we also report separate estimates in Afghanistan for three different measures of violent incidents. 
[INSERT TABLE 2 ABOUT HERE.]

Our key finding is reported in Table 2: the estimated coefficient on unemployment is consistently negative in all three conflicts. Higher unemployment predicts less violence. This result remains true even after controlling for a wide range of possible confounding factors using time and space fixed effects. In Iraq we reject a positive coefficient in three of the four specifications at the $95 \%$ confidence level, and the fourth at a $90 \%$ confidence level, as reported in the upper panel. The results are stronger for the entire Philippines (second panel), where a positive correlation is rejected with $99 \%$ confidence, and consistently negative but insignificant in the more Muslim provinces where the southern insurgency is concentrated. (A separate and ongoing, communist insurgency was concentrated in the northern Philippines during the sample period.) In Afghanistan (third panel) the coefficient is positive in the cross-sectional regression, which includes only the ethnicity controls, but omits other time invariant factors. The estimate is consistently negative and statistically significant once we control for all fixed effects, regardless of the measure of violence used. The p-values for a one tailed test for the AGE, JOIIS and CIDNE measures, using fixed effects, are all 0.08 (by coincidence).

The statistical power of Table 2 lies not in the individual coefficient estimates but in their combination. Separated by time and space, each case yields additional information about the relationship between unemployment and insurgent violence. Interpreting exactly how that information should affect our beliefs requires being specific about the sampling scheme and correlation between countries. The three countries examined are a sample of opportunity, so they are not representative of the full population of countries experiencing insurgent violence. Nevertheless, our criterion for sampling was not the correlation of unemployment and violence, so that there is no particular bias incurred by conducting inference by combining information across these countries. (If there were, inference based on micro-data from any given country would be subject to the same critique.) Samples within countries are representative, so combining information across countries can be understood as testing a null hypothesis about the 
correlation of unemployment and insurgent violence in countries that were at risk of inclusion in our sample of opportunity. ${ }^{18}$

With parameter estimates from three separate conflicts, we can jointly test the hypothesis that the relationship between conflict and unemployment is nonzero i.e., $\mathrm{H}_{0}$ : $\beta_{\text {afghanistan }}=\beta_{\text {philippines }}=\beta_{\text {iraq }}=0$, using a Wald test. Assuming our asymptotic inference is valid in the three individual cases, then, by the Cramer-Wold device, a vector of the three elements will converge in distribution to a multivariate normal distribution. Because the countries in our sample all had a U.S. occupation or heavy involvement, the probability that we reject the null may be correlated, so it makes sense to explicitly incorporate that correlation into a joint hypothesis test. Figure 1 uses that distribution to graph the p-value at which we reject the null that the relationship is nonnegative in all three conflicts against the correlation coefficient between the standard error estimates. ${ }^{19}$ If the parameter estimates are perfectly uncorrelated, then each case truly constitutes an additional test. If estimates are perfectly correlated, the additional tests yield no additional information. The Figure illustrates that moving from zero correlation to the coefficient of correlation which maximizes the $p$-value $(0.44)$ causes our $p$-value to increase from 0.0041 to $0.0224 .{ }^{20}$ However, we still reject the null in this two-tailed test with $95 \%$ confidence.

\section{[INSERT FIGURE 1 ABOUT HERE.]}

18 Those would be countries where sub-national panel data about both unemployment and rebel violence are available or could be constructed - the population that researchers can possibly use for statistical inference. To our knowledge this list includes Afghanistan, Colombia, Guatemala, India, Iraq, Israel, Nepal, Northern Ireland, Pakistan, the Philippines, Spain, and Vietnam. We thank an anonymous referee for emphasizing the need to clarify the sampling scheme.

${ }^{19}$ A convenient feature of multivariate normal distributions is that the covariance in the $(i, j)$ th position of the variance-covariance matrix is equal to $\rho \operatorname{SE}\left(\beta_{i}\right) \operatorname{SE}\left(\beta_{j}\right)$ where $\operatorname{SE}\left(\beta_{i}\right)$ is the estimated standard parameter error for country $\mathrm{i}$.

20 The relationship between the degree of correlation between country coefficents and the $\mathrm{p}$-value at which the null of joint zero is rejected can be non-monotonic. Please see Appendix 1 for a discussion. 
An alternative approach makes the statistical power that comes from combining estimates across countries more intuitive. If we assume complete independence of the tratios across countries, we can treat them as three independent hypothesis tests. Because the probability of three independent events occurring - in this case, falsely rejecting the null in each of the three countries - is just a product of the probability that the individual events occur, we can multiply probabilities to form a joint test. If we start with the prior that unemployment and violence are positively correlated in all three countries, i.e., $\mathrm{H}_{0}: \beta$ $>0$, then, based on the fixed effects estimates for the entire countries in the second column from the right, top three panels, the three joint one-tailed tests would be rejected at a significance level of $(1-.1 * .01 * .1=) 99.99 \%{ }^{21}$. Alternatively, if the prior were that the relationship is nonnegative, i.e., $\mathrm{H}_{0}: \beta=0$, then the three joint two-tailed tests would reject the null at $(1-.2 * .01 * .2=) 99.96 \%$, again based on the second column from the right, top three panels ${ }^{22}$. Even if we assume the p-value maximizing degree of correlation in country parameter estimates above, we still reject the null with $97.8 \%$ confidence. The likelihood of falsely rejecting the null of a nonnegative relationship between unemployment and violence, when these results are combined across countries, is very small.

An alternative estimation approach when using count data is to assume a functional form and estimate using maximum likelihood methods. Supplemental Table S1 takes that approach, assuming a negative binomial probability distribution for the data generating process-a generalization of a Poisson process that allows for arbitrary variance. The advantage of this approach is a gain in both precision and consistency, if the assumed functional form is correct. The disadvantages are inconsistency if the distribution is not negative binomial and no latitude to allow for serial correlation in the error terms-running the risk of overstating precision. In practice, Table S1 reports qualitatively similar results. In the fixed effects specification, which is preferred because

${ }^{21}$ The actual product of $\mathrm{p}$-values from a one-tailed test is 0.0000069 .

${ }^{22}$ Note rejection at $99.96 \%$ confidence implies a p-value with zero correlation of 0.04 , which is greater than the 0.0156 we found assuming zero correlation in the Wald test. This is principally because our p-values in the individual country t-tests are not perfectly equal to $.1, .01$, and .1 cutoffs. 
it allows for the greatest control over unobserved district-specific contributors to violence, the correlation of unemployment and violence is negative in all the national samples. The basic finding is robust to non-linear specifications.

Recall that while the prediction of the opportunity cost model on the link between wages and the number of insurgents was unambiguously negative in the discussion above, the link to violence was muted by the possibility of uncontested spaces, allowing the possibility that increased unemployment (by reducing wages) may have no effect on violence. That is of particular interest in Afghanistan over the sample period, where the violence is concentrated in Pashtun majority regions which also contain a large number of areas that go uncontested by the governments for long periods of time. To ensure that our results are not driven by lack of contestation in some areas with high unemployment Supplemental Table S2 reports estimates including an interaction term for Pashtun majority districts. The negative correlation of unemployment and violence is in fact concentrated in these regions, providing strong evidence that the results for Afghanistan are not spurious. The coefficients on the interaction term are strongly negative. In a regression using only Pashtun regions (bottom panel of Table 2) we reject the positive null at statistical levels of .05. (In the remaining Pashtun minority regions the fixed effects estimates are two statistical zeros and one small positive coefficient (for the CIDNE incident measure the coefficient is 0.0033 and the $t$ ratio is 1.60 ). Those estimates are consistent with the idea that any positive correlation between unemployment and violence is being muted in the Pashtun majority regions by a weak correlation between insurgent strength and violence, but that idea cannot explain the negative coefficient estimates. Some other mechanism must be in play to explain these results. ${ }^{23}$

Figure 2 illustrates the mild negative correlation in Afghanistan between changes in AGE incidents and changes in unemployment, conditional on covariates. A regression line reproduces the coefficient in the second column of results of the third panel of Table 2, with slope -0.049 . The size of the circle for each district is proportional to population. It is clear from the figure that

${ }^{23}$ Appendix Table $\mathrm{S} 2$ reports on further robustness checks for the Afghan regressions reported in Table 2. 
this negative correlation is not due to a few large outliers, but that the pattern is consistent across many districts. ${ }^{24}$

\section{[INSERT FIGURE 2 ABOUT HERE.]}

These negative coefficients are particularly striking when we consider that they are probably biased upwards by a reverse-causal relationship in which violence increases unemployment through the damage it does to the economy. They are also large, at least in Iraq, indicating that a $10 \%$ increase in unemployment from the mean level (from $10 \%$ to $11 \%$ ) is associated with 0.74 less attacks per 1000 per district-quarter for the entire country, about three times the sample mean. In Baghdad the associated decrease is over twice that large, at 1.96 less attacks. While we can't learn too much statistically from three waves of nine districts in Baghdad, it does illustrate the pattern we see throughout Iraq. ${ }^{25}$

These results do not imply that policies which increase employment rates cause violence, since the variation in unemployment rates that's negatively correlated with violence is not necessarily due to exogenous changes in labor demand. For instance, it may instead be due to enhanced intrusive security efforts that reduce both employment and violence. Yet this negative correlation must lead us to doubt whether job creation policies actually decrease violence. What they certainly suggest is that the relationship between employment and violence is perhaps more complex than has been commonly

\footnotetext{
${ }^{24}$ Figure 2 also provides additional evidence against the relationship being a spurious result of trying to fit a linear model when the true relationship is one where violence is decreasing at high levels of unemployment because areas under insurgent control go uncontested. If that were the case, we would see outliers clustered below the regression line at high and low levels of unemployment.

${ }^{25}$ Appendix figure 1 plots the data for Baghdad to illustrate the fixed effects regression in the rightmost column, with changes in incidents plotted against changes in unemployment rates in both 2004-05 and 2005-07. The very small district of Tarmia is omitted from the Figure as it is an outlier and forces rescaling of the graph. It is included in the regression analysis in Table 2. It has no substantial effect on the results. The figure shows our Iraq results are not driven by any particular outlier, but rather by the pattern that played out in some of Baghdad's largest districts: violence fell while unemployment rose in Sadr City, Al-Resafa and Adhamiya in 2004-05, but subsequently rose while unemployment fell in the same three districts in 2005-07.
} 
assumed. To probe possible explanations for this pattern we now turn to a closer examination of the Iraqi insurgency where the negative correlation between unemployment and violence is strongest.

\section{The 'Surge' and the 'Anbar Awakening'}

The first obvious concern with the results from Iraq in Table 2 is that they may be driven by factors not controlled for by region and year fixed effects. Suppose, for example, that the -surge" in Baghdad (which began in January 2007) reduced violence but also strangled the local economy as military units built walls around specific neighborhoods and established checkpoints through the city. We would then observe a negative correlation between unemployment and violence not because unemployment increases violence but because the surge increased the former while reducing the latter. Alternatively, we might have spurious effects because of the politically driven reduction in violence in Sunni areas between August 2006 and December 2007, due to the Anbar awakening', though it is not clear why these would be associated with increased unemployment. To explore these possibilities we re-ran the basic fixed-effect regressions for Iraq but separated the sample by period and region. Table 3 reports these results.

\section{[INSERT TABLE 3 ABOUT HERE.]}

As the Table shows, we can again reject the null hypothesis of a positive correlation between unemployment and violence at the $90 \%$ confidence level for the full three years observed. In Baghdad the data strongly reject a positive correlation in both 2004-05 and over the entire sample period. The negative correlation becomes substantially weaker in Baghdad during the 2005-07 interval that spans both the pre-surge," and -surge" periods, allowing us to rule out the possibility that our results reflect either: (1) the building of walls and placement of additional troops in Baghdad in 2007 which caused both high unemployment and low violence; or (2) the major changes in patterns of violence from mid-2006 on in Baghdad. The data do not allow us to rule out a spurious effect associated with the Anbar awakening, as data from one province provide 
insufficient precision, yet it is unclear why that process -which reduced violence, would be associated with increased unemployment.

\section{Replication}

Are these results somehow particular to officially collected incident data? The top panel of Table 4 replicates the results in Table 3 using the Iraq Body Count data. These are included here in an effort to expose our core results to the possibility of refutation, using a second Iraqi dataset, this one based on press reports rather than on administrative data. The Table reports the results of a regression of incidents in which civilians were killed on unemployment rates, whether those incidents were insurgent, sectarian or coalitioninduced. (Coalition-induced civilian casualty incidents are relevant because they often occur when coalition forces are unexpectedly faced with a strong insurgent threat, inducing the use of imprecise methods such as air strikes to extract themselves safely.) The results are not very informative, as they are not statistically significant-regardless of perpetrator; but they certainly do not show a positive correlation of unemployment and violence.

\section{[INSERT TABLE 4 ABOUT HERE.]}

The lower panel of Table 4 repeats the exercise using as an outcome measure the number of civilian casualties rather than the number of incidents involving civilian casualties. Here a positive correlation appears for Insurgent-perpetrated casualties, though only in Baghdad. This exception in Baghdad may appear to be supportive evidence for an opportunity cost theory, but it is more likely evidence of a tactical failure by insurgents. Recall that these are incidents in which insurgents targeted coalition forces but killed civilians. We know from internal insurgent documents that many groups regard collateral damage - as distinct from intentionally targeting civilians - as politically problematic (Fishman and Moghadam, 2008), a fact we will use in the next section to help distinguish possible mechanisms for our results. 


\section{Why does unemployment correlate with less violence?}

The negative correlation between unemployment and violence directed at government forces is inconsistent with opportunity costs being the dominant mechanism in play. Yet what is the first order connection between labor markets and violence? The result is consistent with at least three theories: (1) predation - insurgent violence rises in economically advantaged periods and areas because those areas become more valuable; (2) security effects - government security efforts simultaneously suppress both economic activity and insurgent violence; and (3) information counterinsurgents can operate more effectively in areas with high unemployment because the cost of information is lower.

Following the logic of Section 3, we attempt to distinguish between these possibilities using data from Iraq and the Philippines, where data on civilian casualties are available. The logic is that if high unemployment proxies for either security measures or low costs of information, low insurgent precision will be predicted by: (1) unemployment; and (b) the interaction of unemployment and population density. Predation has no prediction in this regression. Recall that our insurgent precision variable is calculated as the proportion of attacks on coalition forces that kill no civilians. In Iraq this is calculated as the difference between SIGACT and IBC incidents directed at Coalition and Iraqi forces, divided by SIGACT incidents. In the Philippines civilian casualties are reported directly in the incident data.

Our estimating equation is then,

$$
\text { (2') } \quad p_{r, t}=\mu_{r}+\pi u_{r, t}+\delta d_{r, t}+\theta u_{r, t} d_{r, t}+\gamma_{t}+v_{r t}
$$

where $p$ is insurgent precision, $d$ is population density, $u$ is measured as before (and we ${ }^{6} v$ included a full set of indicators for periods). Security effect and information cost theories predict that the coefficient on unemployment, $\pi$, will be negative in a short regression (equation (1)), and that the coefficient on the interaction, $\theta$, will be negative in this long regression. As before, we don't think of these estimated coefficients as causal effects, but, assuming that any reverse causality between precision and unemployment is second order, we are confident in interpreting the coefficients as tests of the theory. 
Table 5 reports the results of this analysis. Beginning with the upper panel, on Iraq, three facts stand out. First, high unemployment is weakly associated with low insurgent precision in all sample periods, though not significantly so. Second, if we include population density and an interaction term in the regression, we find that insurgent precision is lower in densely populated areas during both sub-periods. ${ }^{26}$ This makes sense, as civilians are unfortunately more likely to be affected by shrapnel, overpressure, and stray small arms fire in densely-populated areas. Third, and most importantly, once we control for this density effect we find a strong negative coefficient on the interaction term between unemployment and population density, indicating that in the dense urban districts of Iraq unemployment was associated with reduced precision in both sub-periods (columns four and six) and over the entire sample period (column two). This last result is consistent with both the security effects and information costs explanations for the negative correlation.

\section{[INSERT TABLE 5 ABOUT HERE.]}

The results from the Philippines are quite similar. Unemployment predicts significantly less violence in the pooled regression and in second sample period, 2001-3 and 2006 (column 5). The coefficient in the first sample period is positive but not statistically significant. When the interaction of unemployment and violence is inserted the coefficient on that term is negative and highly significant in the second period (column 6), as predicted by both security effects and information cost theories. The same is true in the regression that pools both periods (column 2).

Taken as a whole these results are consistent with the conjecture that insurgents switch tactics when unemployment is high, restricting themselves to methods that reveal less information but allow less precise targeting of coalition forces (e.g., sensor-activated

\footnotetext{
${ }^{26}$ Note also that population density is sufficiently time-varying in Iraq during the war to allowing coefficients to be precisely estimated in a fixed-effects regression. This reflects tragically high rates of internal displacement and refugee migration.
} 
IEDs vs. command-detonated ones) and thus inadvertently kill more civilians. What we cannot determine from these data is whether that tactical switch is due to 1) increased security pressure, such as checkpoints, barriers, and patrols - that raise unemployment by restricting the movement of goods and services; or 2) improved information flows to coalition forces about insurgent activities, as the price of leaks declines when unemployment rises. These results are neutral with respect to the predation hypothesis. ${ }^{27}$ Recalling a grievance-based mechanism that motivated our original discussion, it's worth noting that Table 5 provides additional evidence refuting the idea that it is a dominant force; assuming that unhappy or unemployed noncombatants are less likely to share tips with the government - just as they are thought to be less likely to join the insurgencyone would expect insurgent precision to be high in areas with high unemployment. Table 5 shows the opposite.

\section{Conclusion}

Our findings on the relationship between unemployment and insurgency in Afghanistan, Iraq and the Philippines call into question the opportunity cost theory that dominates thinking in policy circles. These results suggest that any opportunity cost effects - at least in these three cases - are overshadowed by other forces. Combining data from three insurgencies allows us to emphatically reject a positive correlation between unemployment and violence.

Why is higher unemployment associated with less violence? While we cannot say for certain, a closer look at the data from Iraq and the Philippines suggests that the pattern stems from the relationship between local economic conditions and counter-insurgents ‘ efforts to combat violence, not from the labor market for insurgents. The data are consistent with two possibilities. The first is that as local economic conditions deteriorate, the price of information falls and government forces and their allies can buy more intelligence on insurgents, undermining insurgent operations. The second is simply that the techniques used to enhance

\footnotetext{
${ }^{27}$ The insurgent precision results are also neutral with respect to the additional possibility that increased violence induces migration disproportionately among working-aged adults, which in turn reduces the unemployment rate, generating a negative correlation. We think that this is unlikely, especially in low-mobility rural communities, but cannot rule out the possibility with these data.
} 
security - establishing checkpoints, building barriers and conducting raids - inhibit commerce and damage the economy. Distinguishing between those alternatives, and establishing the importance of predation, is a task for future research. What we can say with confidence is that while it may still be true that increasing unemployment causes greater political violence on the margins, that effect is swamped by other mechanisms. Greater unemployment in these three conflicts predicts less political violence, not more.

Our research presents two serious policy implications for academics, donor countries, and aid organizations. First, the negative correlation of unemployment with violence indicates that aid and development efforts that seek to enhance political stability through short-term job creation programs may well be misguided. Instead, development funds are likely to buy more no-bang for the buck' when directed at small-scale projects that improve the quality of local government services, thereby inducing noncombatants to share intelligence about insurgents with their government and its allies. We find evidence for just such an effect in related research on the impact of U.S. reconstruction spending in Iraq (Berman, Shapiro and Felter, 2008).

Second, much more basic research is required to guide development aid spent in efforts to rebuild social and political order. These programs are not methodically evaluated the way comparable domestic programs would be. This is a tragedy. Aid resources are scarce and the needs massive. A better understanding of how, when, and where aid spending helps reduce political violence will both further our understanding of insurgencies, while helping to guide practitioners in applying limited development aid in conflict and post-conflict societies. 


\section{References}

Akerlof, George and Janet L. Yellen. 1994. -Gang Behavior, Law Enforcement, and Community Values." in Values and Public Policy. Henry J. Aaron, Thomas E. Mann, and Timothy Taylor eds. Washington, D.C.: The Brookings Institution.

Al Jazeera (2009), Key Quotes from new Taliban book," posted July 27, 2009. http://english.aljazeera.net/news/asia/2009/07/200972775236982270.html .

Becker, G. -Erime and Punishment: An Economic Approach," Journal of Political Economy. 76, 169-217 (1968).

Benmelech, Efraim, Claude Berrebi and Esteban F. Klor. 2010 -Counter-Suicide-Terrorism: Evidence from House Demolitions." NBER Working Paper 16493.

Berman, Eli. 2009. Radical, Religious and Violent: The New Economics of Terrorism (MIT Press, Cambridge MA.)

Berman, Eli and David. D. Laitin. 2008. - Rligion, Terrorism and Public Goods: Testing the Club Model." Journal of Public Economics 92(10-11): 1942-1967.

Berman, E., J. N. Shapiro, J. H. Felter, - Can Hearts and Minds be Bought? The Economics of Counterinsurgency in Iraq." NBER Working Paper 14606 (December 2008).

Blattman, Christopher and Miguel, Edward, Civil War (March 2009). NBER Working Paper \#14801

Brainard, L., and D. H. Chollet, fntroduction," in . Too Poor for Peace? Global Poverty, Conflict, and Security in the 21 st Century, L. Brainard, D. H. Chollet, Eds. (Brookings, Washington DC, 2007).

Cassidy, R. Counterinsurgency and the Global War on Terror (Praeger, Westport, 2006).

Chiarelli, P. U.S. Army Commander, Multinational Corps Iraq, press briefing, December 8, 2006.

Clutterbuck, R. The Long Long War: Counterinsurgency in Malaya and Vietnam (Praeger, Ann Arbor, 1966).

Collier, Paul and Anke Hoeffler. 2004. -Greed and Grievance in Civil War." Oxford Economic Papers 56: 563-595.

Combating Terrorism Center, US Military Academy, 2006. - Captured Zarqawi Network Letters from Iraq" posted April 20 2006, www.ctc.usma.edu/harmony/harmony.asp. 
Crain, Charles. 2007. Behind the Baghdad Wall.” Time, May 9.

Department of Defense, Measuring Stability and Security in Iraq: March 2008 Report to Congress in Accordance with the Department of Defense Appropriations Act 2008 (2008; http://www.globalsecurity.org/military/library/report/2008/iraq-securitystability_mar2008.pdf).

Dube, Oeindrila and Juan Vargas - Commodity Price Shocks and Civil Conflict: Evidence from Columbia," Harvard University mimeo, October 2008.

Fearon, J. Economic Development, Insurgency, and Civil War" in Institutions and Economic Performance, E. Helpman, Ed. (Harvard University Press, Cambridge, MA, 2008).

Fearon, James D. and David D. Laitin. 2003. - Hhicity, Insurgency, and Civil War." American Political Science Review 97: 75-90.

Fischer, Stanley, Patricia Alonso-Gamo, and Ulric Erickson von Allmen, 2001. Economic Developments in the West Bank and Gaza since Oslo," The Economic Journal, 111 (June), F254-F275.

Fishman, B., and Moghadam, A., (eds.) Bombers, Bank Accounts, and Bleedout: AlQa'ida in Iraq's Road In and Out of Iraq. (Combating Terrorism Center, US Military Academy, 2008).

Galula, D. Counterinsurgency Warfare; Theory and Practice (Praeger, New York, 1964). Government Accountability Office, The Department of Defense's Use of Solatia and Condolence Payments in Iraq and Afghanistan (GAO publication 07-699, 2007; http://www.gao.gov/products/GAO-07-699).

Grogger, Jeff, 1998. "Market Wages and Youth Crime," Journal of Labor Economics, University of Chicago Press, vol. 16(4), pages 756-91, October.

Grossman, H. A General Equilibrium Model of Insurrections." American Economic Review. 81, 912-921 (1991).

Gould, Eric D. and Bruce A. Weinberg \& David B. Mustard, 2002. "Crime Rates And Local Labor Market Opportunities In The United States: 1979-1997," The Review of Economics and Statistics, MIT Press, vol. 84(1), pages 45-61, February.

Hendawi, Hamza. 2008. Baghdad's walls keep peace but feel like a prison.” Associated Press, June 27, 2008. 
Hidalgo, F. Daniel, Suresh Naidu, Simeon Nichter, and Neal Richardson. 2010. Economic Determinants of Land Invasions. Review of Economics and Statistics, 92 (3), 505-523

Kalyvas, S. N. The Logic of Violence in Civil War (Cambridge Univ. Press, New York, 2006).

Kanaan, Osama (1998) Private Investment Under Uncertainty in the West Bank and Gaza Strip,” in Barnett, S. Calika N., Chua D., Kanaan, O., and Zavadjuil, M., The Economy of the West Bank and Gaza Strip: recent experience, prospects and challenges to private sector development. Washington DC: International Monetary Fund.

Kitson, F. Low Intensity Operations: Subversion, Insurgency, Peace-keeping (Stackpole, Harrisburg, 1971).

Komer, Robert. 1972. The Malayan Emergency in Retrospect: Organization of a Successful Counterinsurgency Effort. (Santa Monica, CA: RAND, R-957)

Long, Austin. 2006. On “Other War”: Lessons from Five Decades of RAND Counterinsurgency Research (Santa Monica, C.A.: RAND).

Mao, Z. On Guerilla Warfare, S. B. Griffin, Trans. (Univ. Illinois Press, Champaign, 2000). [orig. published 1937]

McMaster, H.R., 2008, -n War: Lessons to be Learned”, Survival, Volume 50, Issue 1, Feb.

Miguel, E., S. Satyanath, and E. Sergenti. 2004. Economic shocks and civil conflict: An instrumental variables approach. Journal of Political Economy 112, 725-753

Multi-National Corps Iraq. 2009. Money As A Weapons System (MAAWS): MNC-I CJ8 SOP. Available at http://publicintelligence.net/money-as-a-weapon-system-maaws/.

Petraeus, David. 2006. Eearning Counterinsurgency: Observations from Soldiering in Iraq", Military Review, Jan-Feb.

Popkin, S. L. The Rational Peasant: The Political Economy of Rural Society in Vietnam (Univ. of California Press, Berkeley, 1979).

Raphael, S. and R. Winter-Ebmer (2001), Identifying the effect of unemployment on crime‘. Journal of Law and Economics 44, 259-283.

Rhode, David and David E. Sanger. 2007. How the Good War' in Afghanistan Went Bad.” New York Times, August 12, 2007. 
Sepp, Kalev, 2005," Best Practices" in Counterinsurgency," Military Review, May/June.

Taber, R. The War of the Flea: A Study of Guerilla Warfare Theory and Practice (Lyle Stuart, New York, 1965).

Thompson, R. G. K. Defeating Communist Insurgency: The lessons of Malaya and Vietnam, Studies in International Security (Praeger, New York, 1966).

Trinquier, R. 1961. Modern Warfare: A French View of Counterinsurgency, Trans. D. Lee (Praeger, New York, 1961).

Warrick, Joby. 2008. -EIA buys Afghan chief's loyalty with Viagra," Washington Post, 26 December. http://sfchronicle.us/cgibin/article.cgi?f=/c/a/2008/12/26/MN0S14V9PR.DTL accessed June 62010.

United States Army. 2006. The U.S. Army Counterinsurgency Field Manual (U.S. Army Field Manual No. 3-24; http://www.fas.org/irp/doddir/army/fm3-24fd.pdf). 
TABLES FOR TEXT INSERTION

Table 1: Summary Statistics for Population, Unemployment, and Violence

\begin{tabular}{|c|c|c|c|c|c|}
\hline & Variable & Mean & Std. Dev. & Min & Max \\
\hline \multirow{14}{*}{$\begin{array}{c}\text { Iraq } \\
\text { (district/quarter) }\end{array}$} & Population (district) & 605,340 & 464,106 & 10,966 & $1,624,058$ \\
\hline & Unemployment (rate) & .117 & .063 & 0 & 0.495 \\
\hline & Sunni vote share (governorate) & .207 & .250 & 0 & .917 \\
\hline & Population density $\left(1,000 / \mathrm{km}^{2}\right)$ & 1.53 & 3.13 & .000286 & 13.62 \\
\hline & SIGACT incidents / 1000 & .258 & .504 & 0 & 8.54 \\
\hline & \multicolumn{5}{|c|}{ Iraq Body Count (IBC) incidents / 1000} \\
\hline & Insurgent & .005 & .011 & 0 & .240 \\
\hline & Sectarian & .013 & .026 & 0 & .340 \\
\hline & Coalition & .002 & .006 & 0 & .140 \\
\hline & \multicolumn{5}{|l|}{ IBC civilian casualties / 1000} \\
\hline & Insurgent & .018 & .043 & 0 & .611 \\
\hline & Sectarian & .046 & .159 & 0 & 1.70 \\
\hline & Coalition & .015 & .102 & 0 & 1.32 \\
\hline & Insurgent precision & .923 & .159 & 0 & 1 \\
\hline \multirow{5}{*}{$\begin{array}{l}\text { Philippines } \\
\text { (province/year) }\end{array}$} & Population (province) & $1,002,281$ & $1,271,405$ & 15,095 & $11,321,875$ \\
\hline & Unemployment (rate) & .105 & .039 & 0 & .201 \\
\hline & Percent Muslim & .053 & .181 & 0 & .993 \\
\hline & Rebel initiated incidents / 1000 & .010 & .024 & 0 & .213 \\
\hline & All non-criminal incidents / 1000 & .034 & .070 & 0 & 1.13 \\
\hline \multirow[t]{2}{*}{$\mathrm{N}=624$} & Civilian casualties / 1000 & .015 & .042 & 0 & 659 \\
\hline & Insurgent precision & .816 & .309 & 0 & 1 \\
\hline \multirow{5}{*}{$\begin{array}{c}\text { Afghanistan } \\
\text { (district/month) }\end{array}$} & Population (district) & 77,7804 & $1,410,510$ & 2,462 & $4,017,898$ \\
\hline & Unemployment (rate) & .241 & .206 & 0 & 1 \\
\hline & Percent Pashtun & .385 & .389 & 0 & 1 \\
\hline & Percent males & .522 & .094 & 0 & 1 \\
\hline & Average household size & 9.56 & 1.73 & 5.84 & 21.1 \\
\hline \multirow[t]{3}{*}{$\mathrm{N}=2,160$} & AGE incidents/ 1000 & .049 & .152 & 0 & 2.18 \\
\hline & JOIIS incidents/ 1000 & .083 & .225 & 0 & 2.90 \\
\hline & CIDNE incidents/ 1000 & .046 & .154 & 0 & 2.13 \\
\hline
\end{tabular}

Sources:

- Unemployment and population: Iraq Living Conditions Survey (ILCS) (March and April 2004), World Food Program Food Security and Vulnerability Analysis in Iraq (June and July 2005; November and December 2007), Republic of the Philippines Census Organization, Labor Force Survey (LFS) for 1997 through 2003 and 2006, Afghan National Quarterly Assessment Report (ANQAR) surveys wave 1 (September 2008) through wave 5 (September 2009), LandScan ${ }^{\mathrm{TM}}$ population.

- Violence: Empirical Studies of Conflict Philippine project, internal security incidents, Armed Forces of the Philippines, 1975-2008; Multi-National Forces Iraq SIGACTS III Database; Joint Operations - INTEL Information System (JOIIS), Combined Information Data Network Exchange (CIDNE). Iraq Body Count.

- Other: Sunni vote share in Iraq is based on the December 2005 elections. Muslim population share in the Philippines is from the 1995, 2000, and 2007 censuses. Pashtun population share, male population share, adult population without any formal schooling share, and average household size in Afghanistan are from ANQAR.

All means are population weighted 
Table 2: Unemployment and Violent Incidents in Iraq, the Philippines, and Afghanistan

\begin{tabular}{|c|c|c|c|c|c|}
\hline & \multirow{3}{*}{$\begin{array}{l}\text { DV } \\
\text { Region }\end{array}$} & \multicolumn{4}{|c|}{ Linear Regression } \\
\hline & & $\begin{array}{l}\text { Incidents } \\
/ 1000\end{array}$ & $\begin{array}{l}\text { Incidents } \\
\quad / 1000\end{array}$ & $\begin{array}{l}\text { Incidents } \\
/ 1000\end{array}$ & $\begin{array}{l}\text { Incidents } \\
\quad / 1000\end{array}$ \\
\hline & & All & Baghdad & All & Baghdad \\
\hline \multirow{6}{*}{$\begin{array}{c}\text { Iraq } \\
\text { (district/quarter) }\end{array}$} & Unemployment & $\begin{array}{c}-1.118^{* *} \\
(0.542)\end{array}$ & $\begin{array}{c}-4.254^{* * *} \\
(1.460)\end{array}$ & $\begin{array}{l}-0.709^{*} \\
(0.552)\end{array}$ & $\begin{array}{c}-1.847 * * * \\
(0.566)\end{array}$ \\
\hline & Observations & 312 & 27 & 312 & 27 \\
\hline & R-squared & 0.23 & 0.35 & 0.06 & 0.16 \\
\hline & Controls & Ethnicity & Ethnicity & District FE & District FE \\
\hline & $\overline{\mathrm{DDV}}$ & $\begin{array}{c}\text { Incidents } \\
/ 1000\end{array}$ & $\begin{array}{c}\text { Incidents } \\
/ 1000\end{array}$ & $\begin{array}{c}\text { Incidents } \\
/ 1000\end{array}$ & $\begin{array}{c}\text { Incidents } \\
/ 1000\end{array}$ \\
\hline & Region & All & Muslim $>5 \%$ & All & Muslim > 5\% \\
\hline \multirow{5}{*}{$\begin{array}{c}\text { Philippines } \\
\text { (province/year) }\end{array}$} & Unemployment & $\begin{array}{c}-0.131 * * * \\
(0.031)\end{array}$ & $\begin{array}{l}-0.148 \\
(0.174)\end{array}$ & $\begin{array}{c}-0.152 * * * \\
(0.049)\end{array}$ & $\begin{array}{l}-0.113 \\
(0.132)\end{array}$ \\
\hline & Observations & 624 & 96 & 624 & 96 \\
\hline & R-squared & 0.33 & 0.35 & 0.141 & 0.354 \\
\hline & Controls & Ethnicity & Ethnicity & Province FE & Province FE \\
\hline & $\overline{\mathrm{DDV}}$ & AGE/1000 & AGE/1000 & JOIIS/1000 & CIDNE/1000 \\
\hline \multirow{3}{*}{$\begin{array}{l}\text { Afghanistan } \\
\text { (district/month) }\end{array}$} & Unemployment & $\begin{array}{c}0.032 * * \\
(0.018)\end{array}$ & $\begin{array}{l}-0.049 \\
(0.035)\end{array}$ & $\begin{array}{l}-0.063^{*} \\
(0.044)\end{array}$ & $\begin{array}{l}-0.049 \\
(0.035)\end{array}$ \\
\hline & Observations & 2,160 & 2,160 & 2,160 & 2,160 \\
\hline & R-squared & 0.17 & 0.08 & 0.105 & 0.075 \\
\hline
\end{tabular}

Controls Ethnicity District FE District FE District FE

\begin{tabular}{cccccc}
\hline \hline & DV & AGE/1000 & AGE/1000 & JOIIS/1000 & CIDNE/1000 \\
\hline \multirow{2}{*}{$\begin{array}{c}\text { Afghanistan } \\
\text { majority Pashtun }\end{array}$} & Unemployment & $0.092^{* *}$ & $-0.158^{* *}$ & $-0.191^{*}$ & $-0.163^{*}$ \\
& & $(0.054)$ & $(0.085)$ & $(0.106)$ & $(0.088)$ \\
& Observations & 923 & 917 & 917 & 917 \\
& R-squared & 0.10 & 0.22 & 0.25 & 0.21 \\
\hline & Controls & Ethnicity & District FE & District FE & District FE \\
\hline
\end{tabular}

Note: All regressions include time/wave fixed effects and are weighted by population. The Afghanistan sample has five waves of ANQAR data and all waves span two months, except wave 5 spanning one month (results are similar using wave-month fixed effects). Robust standard errors clustered by district/province reported in parentheses. ${ }^{* * *} \mathrm{p}<.01, * * \mathrm{p}<.05, * \mathrm{p}<.1$, all for one-tailed test with $\mathrm{H}_{0}: \beta>0$. Variables described in note to Table 1. Iraq has 104 districts, the Philippines have 78 provinces, and Afghanistan has 363 districts included in the samples above. 
Table 3: Unemployment and Violent Incidents in Iraq, by period

Dependent variable: SIGACT incidents

\begin{tabular}{lcccccc}
\hline \hline & \multicolumn{2}{c}{$2004-07$} & \multicolumn{2}{c}{$2004-05$} & \multicolumn{2}{c}{$2005-07$} \\
\hline & All & Baghdad & All & Baghdad & All & Baghdad \\
Unemployment & $-0.709^{*}$ & $-1.847^{* * *}$ & -0.581 & $-2.431^{* * *}$ & -1.321 & $-1.696^{* *}$ \\
& $(0.552)$ & $(0.566)$ & $(0.514)$ & $(0.933)$ & $(1.060)$ & $(0.905)$ \\
& & & & & & \\
\hline Observations & 312 & 27 & 208 & 18 & 208 & 18 \\
$\mathrm{R}^{2}$ & 0.062 & 0.162 & 0.068 & 0.164 & 0.040 & 0.135 \\
\hline
\end{tabular}

Note: Includes year and district fixed effects and are weighted by population. Robust standard errors clustered by district in parentheses. $* * * \mathrm{p}<.01, * * \mathrm{p}<.05, * \mathrm{p}<.1$, all for one-tailed test with $\mathrm{H}_{0}: \beta>0$. Variables described in note to Table 1 .

Table 4: Unemployment and Violence - Iraqi Civilian Casualties Incidents, by Perpetrator

\begin{tabular}{|c|c|c|c|c|c|c|c|c|c|}
\hline $\begin{array}{l}\text { Perpetrator of } \\
\text { Incident: }\end{array}$ & \multicolumn{4}{|c|}{ Insurgent } & Sectarian & & \multicolumn{3}{|c|}{ Coalition } \\
\hline \multicolumn{10}{|c|}{ Dependent Variable: Civilian Casualty Incidents } \\
\hline & All & $\begin{array}{c}\text { Not } \\
\text { Baghdad }\end{array}$ & Baghdad & All & $\begin{array}{c}\text { Not } \\
\text { Baghdad }\end{array}$ & Baghdad & All & $\begin{array}{c}\text { Not } \\
\text { Baghdad }\end{array}$ & Baghdad \\
\hline Unemployment & $\begin{array}{l}0.013 \\
(.011)\end{array}$ & $\begin{array}{l}0.016 \\
(.013)\end{array}$ & $\begin{array}{l}0.011 \\
(.010)\end{array}$ & $\begin{array}{l}0.009 \\
(.031)\end{array}$ & $\begin{array}{l}0.011 \\
(.039)\end{array}$ & $\begin{array}{l}-0.023 \\
(.020)\end{array}$ & $\begin{array}{l}0.003 \\
(.008)\end{array}$ & $\begin{array}{l}0.005 \\
(.010)\end{array}$ & $\begin{array}{l}-0.010 \\
(.010)\end{array}$ \\
\hline $\begin{array}{l}\text { Observations } \\
\mathrm{R}^{2}\end{array}$ & $\begin{array}{c}312 \\
0.085\end{array}$ & $\begin{array}{c}285 \\
0.067\end{array}$ & $\begin{array}{c}27 \\
0.380\end{array}$ & $\begin{array}{c}312 \\
0.179\end{array}$ & $\begin{array}{c}285 \\
0.183\end{array}$ & $\begin{array}{c}27 \\
0.665\end{array}$ & $\begin{array}{c}312 \\
0.011\end{array}$ & $\begin{array}{c}285 \\
0.015\end{array}$ & $\begin{array}{c}27 \\
0.134\end{array}$ \\
\hline
\end{tabular}

Dependent Variable: Civilian Casualties

\begin{tabular}{lcccccccccc}
\hline & All & $\begin{array}{c}\text { Not } \\
\text { Baghdad }\end{array}$ & Baghdad & All & $\begin{array}{c}\text { Not } \\
\text { Baghdad }\end{array}$ & Baghdad & All & $\begin{array}{c}\text { Not } \\
\text { Baghdad }\end{array}$ & Baghdad \\
Unemployment & 0.037 & -0.022 & $0.292^{* * *}$ & -0.449 & -0.003 & -2.096 & 0.013 & 0.104 & 0.004 \\
& $(0.047)$ & $(0.038)$ & $(0.054)$ & $(0.430)$ & $(0.111)$ & $(1.731)$ & $(0.046)$ & $(0.099)$ & $(0.061)$ \\
\hline Observations & 312 & 285 & 27 & 312 & 285 & 27 & 312 & 285 & 27 \\
$\mathrm{R}^{2}$ & 0.03 & 0.004 & 0.53 & 0.06 & 0.06 & 0.24 & 0.02 & 0.03 & 0.03 \\
\hline
\end{tabular}

Note: Iraq Body Count data. Includes year and district fixed effects and weighted by population. Robust standard errors clustered by district in parentheses. $* * * \mathrm{p}<.01, * * \mathrm{p}<.05, * \mathrm{p}<.1$, all for one-tailed test with $\mathrm{H}_{0}: \beta>0$. Variables described in note to Table 1 . 
Table 5: Insurgent precision, unemployment, and population density

Dependent variable: Insurgent Precision $=1-($ Insurgent-killings/SIGACTs $)$

\section{4-07}

2004-05

2005-07

Unemployment

$-0.541$

0.230

(0.493)

$(0.179)$

$-0.556$

0.202

(0.683)

(0.133)

$-0.733$

0.281

(0.658)

(0.330)

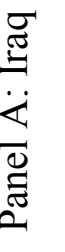

Population Density
Unemployment*
Pop. Density

$-0.243 * * *$

$(0.053)$

$-0.345^{* * *}$

$-0.302 * * *$

$-0.616^{* * *}$

(0.108)

$(0.051)$

(0.041)

$-0.597 * * *$

$-0.717 * * *$

(0.041)

(0.054)

\begin{tabular}{|c|c|c|c|c|c|c|}
\hline Observations & 312 & 312 & 208 & 208 & 208 & 208 \\
\hline $\mathrm{R}^{2}$ & 0.087 & 0.460 & 0.054 & 0.680 & 0.158 & 0.623 \\
\hline $\begin{array}{l}\text { Joint F-Test on unemployment } \\
\text { and interaction term }\end{array}$ & & $237.90 * * *$ & & $219.38 * * *$ & & $277.39 * * *$ \\
\hline
\end{tabular}

$1997-2003 \& 2006$

1997-2000

2001-3 \& 06

\begin{tabular}{|c|c|c|c|c|c|c|}
\hline Unemployment & $\begin{array}{l}-1.196 \\
(1.064)\end{array}$ & $\begin{array}{l}-0.582 \\
(1.075)\end{array}$ & $\begin{array}{c}0.050 \\
(2.130)\end{array}$ & $\begin{array}{c}1.828 \\
(2.163)\end{array}$ & $\begin{array}{c}-3.475 * * \\
(1.784)\end{array}$ & $\begin{array}{l}-1.848 \\
(1.878)\end{array}$ \\
\hline Population Density & & $\begin{array}{c}0.143 * * * \\
(0.051)\end{array}$ & & $\begin{array}{c}-1.941 * * \\
(0.87)\end{array}$ & & $\begin{array}{l}0.350 * * \\
(0.19)\end{array}$ \\
\hline Unemployment * & & $-0.646 * * *$ & & 0.425 & & $-2.288 * * *$ \\
\hline Pop. Density & & $(0.13)$ & & $(0.59)$ & & $(0.68)$ \\
\hline Observations & 624 & 624 & 312 & 312 & 312 & 312 \\
\hline & 0.26 & 0.28 & 0.41 & 0.46 & 0.07 & 0.19 \\
\hline $\begin{array}{l}\text { Joint F-Test on unemployment } \\
\text { and interaction term }\end{array}$ & & $25.99 * * *$ & & 1.21 & & $17.91 * * *$ \\
\hline
\end{tabular}

Note: Includes year and district/province fixed effects and weighted by population.

Robust standard errors clustered by district in parentheses. *** $\mathrm{p}<.01, * * \mathrm{p}<.05$,

$* \mathrm{p}<.1$, two-tailed. Precision set to 1 if no attacks and no civilian casualties, 0 if no attacks and civilian casualties. Other variables described in notes to table 1. 


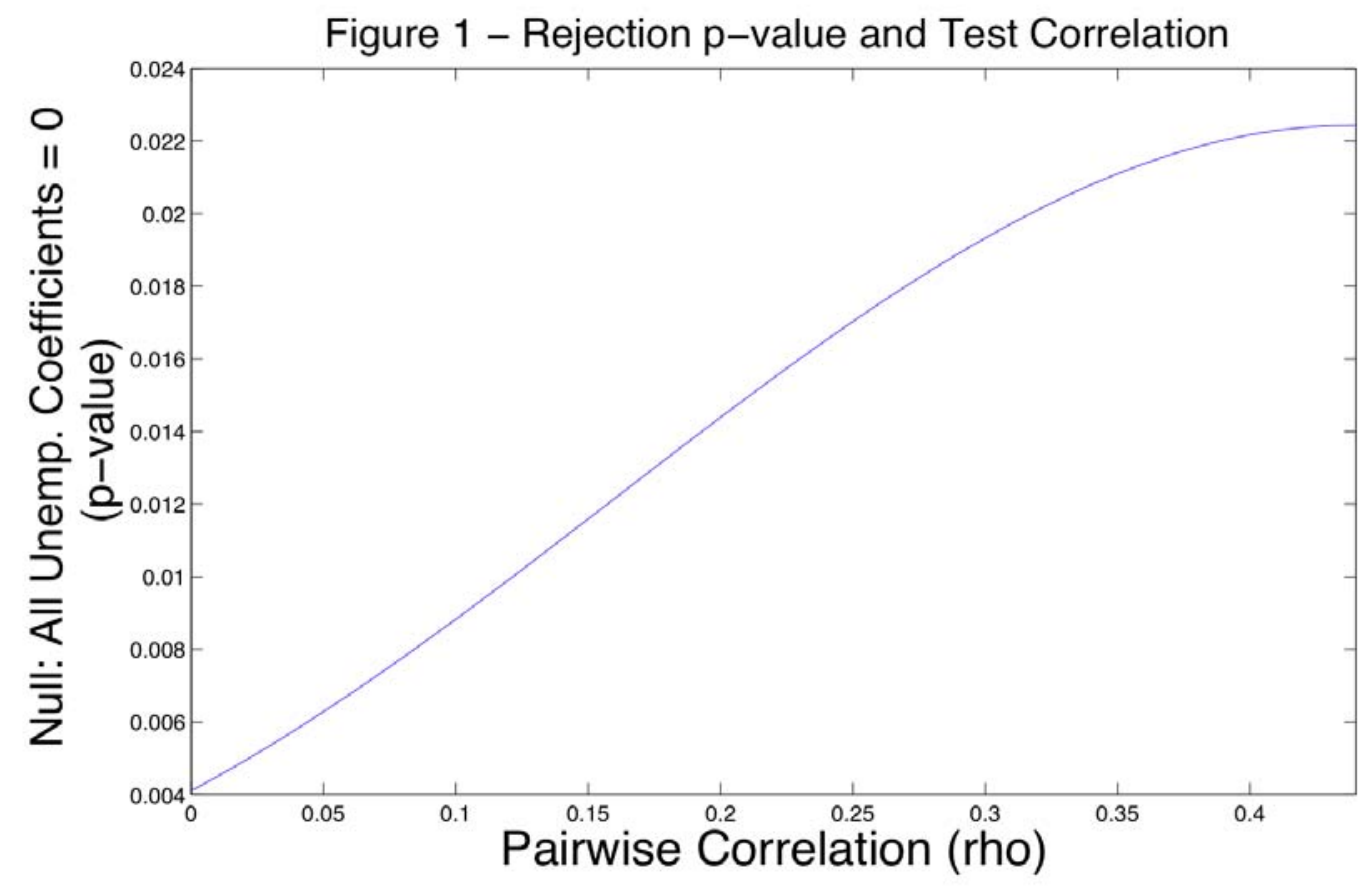

Notes: Rho" is the first multiplying parameter in the $(i, j)$ th off-diagonal term of the variation covariance matrix $\left(\rho \mathrm{SE}\left(\beta_{\mathrm{i}}\right) \mathrm{SE}\left(\beta_{\mathrm{j}}\right)\right)$ for the asymptotic joint distribution of the three individual country parameter estimates. The figure assumes that the pairwise correlation $\rho$ is the same across the three country pairs. The p-value of the joint test declines as $\rho$ increases above .45, because rejection in the high-t country (the Philippines) begins to dominate the inference. For a detailed explanation see Appendix 1. 


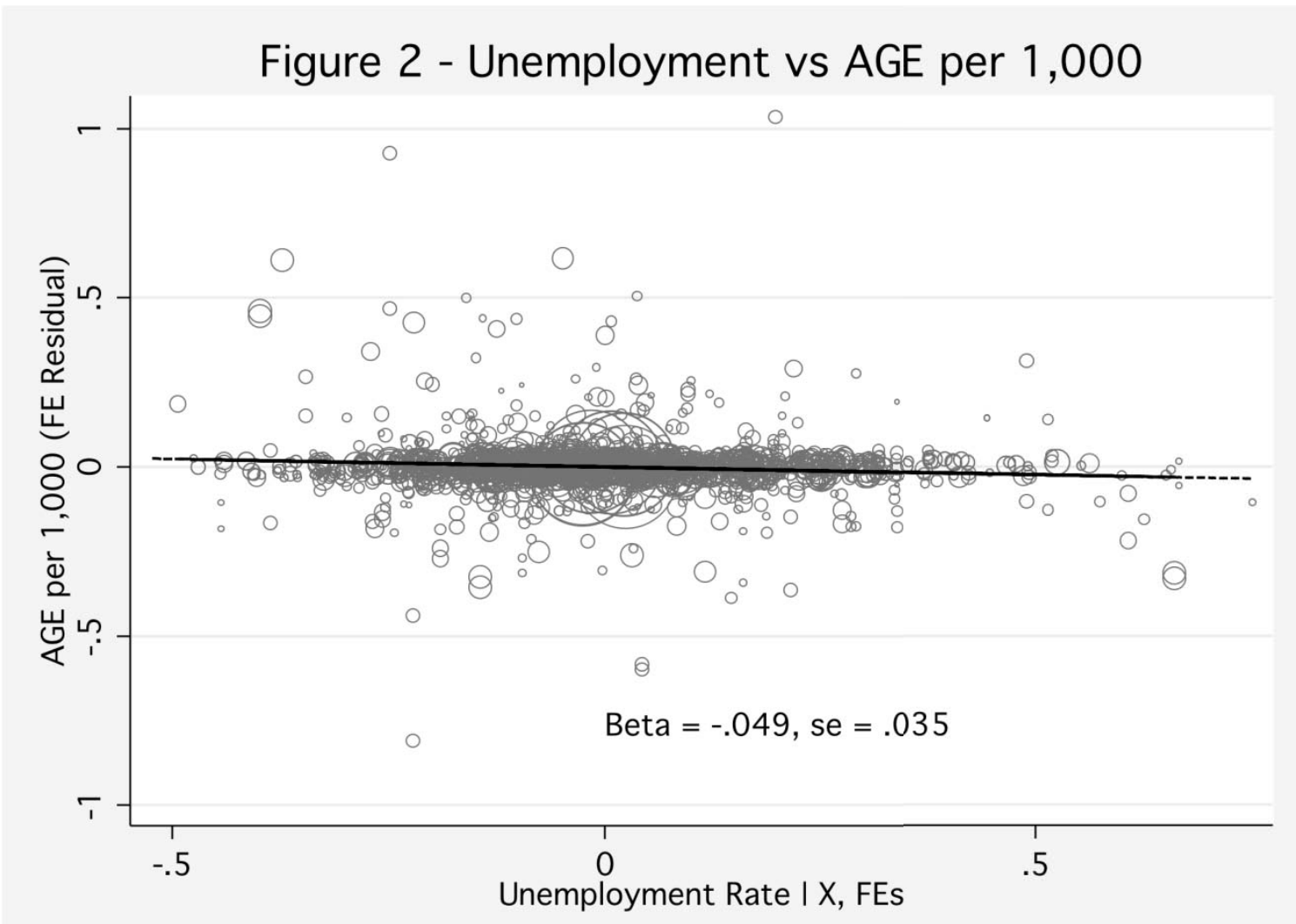

Note: Variables on axes are residuals from table 2, panel 3, column 2 regression that includes fixed effects and regressors ( $X$ ”): percent Pashtun, percent male, percent with no schooling, and average household size. FEs include both wave and district effects. 


\section{Supplemental Tables and Figures}

Appendix Table S1: Unemployment and Violent Incidents in Iraq and the Philippines, Negative Binomial Regression

Negative Binomial Regression

\begin{tabular}{|c|c|c|c|c|c|}
\hline & $\overline{\mathrm{DV}}$ & Incidents & Incidents & Incidents & Incidents \\
\hline \multirow{4}{*}{$\begin{array}{c}\text { Iraq } \\
\text { (district/quarter) }\end{array}$} & Region & All & Baghdad & All & Baghdad \\
\hline & Unemployment & $\begin{array}{c}-5.313 * * * \\
(1.371)\end{array}$ & $\begin{array}{c}-13.66 * * * \\
(2.093)\end{array}$ & $\begin{array}{c}-2.718^{* *} \\
(1.172)\end{array}$ & $\begin{array}{c}-6.672 * * * \\
(2.115)\end{array}$ \\
\hline & Observations & 312 & 27 & 279 & 27 \\
\hline & Controls & $\begin{array}{l}\text { Ethnicity, } \\
\text { Population }\end{array}$ & $\begin{array}{l}\text { Ethnicity, } \\
\text { Population }\end{array}$ & $\begin{array}{l}\text { District FE, } \\
\text { Population }\end{array}$ & $\begin{array}{l}\text { District FE, } \\
\text { Population }\end{array}$ \\
\hline \multirow{4}{*}{$\begin{array}{c}\text { Philippines } \\
\text { (province/year) }\end{array}$} & $\underline{\text { Region }}$ & All & Muslim $>5 \%$ & All & Muslim > 5\% \\
\hline & Unemployment & $\begin{array}{c}-8.199 * * * \\
(2.012)\end{array}$ & $\begin{array}{l}-7.161 * \\
(4.654)\end{array}$ & $\begin{array}{l}-1.156 \\
(2.026)\end{array}$ & $\begin{array}{c}1.816 \\
(3.981)\end{array}$ \\
\hline & Observations & 624 & 96 & 552 & 96 \\
\hline & Controls & $\begin{array}{l}\text { Ethnicity, } \\
\text { Population } \\
\end{array}$ & $\begin{array}{l}\text { Ethnicity, } \\
\text { Population } \\
\end{array}$ & $\begin{array}{c}\text { Province FE, } \\
\text { Population } \\
\end{array}$ & $\begin{array}{c}\text { Province FE, } \\
\text { Population } \\
\end{array}$ \\
\hline \multirow{4}{*}{$\begin{array}{c}\text { Afghanistan } \\
\text { (district/year) } \\
\text { - A } \mathbb{E} " \text { incidents) }\end{array}$} & Region & All & $\begin{array}{c}\text { Pashtun }> \\
50 \%\end{array}$ & All & $\begin{array}{c}\text { Pashtun }> \\
50 \%\end{array}$ \\
\hline & Unemployment & $\begin{array}{c}-0.424 * * * \\
(0.176)\end{array}$ & $\begin{array}{c}0.501 * * \\
(0.237)\end{array}$ & $\begin{array}{l}-0.106 \\
(0.103)\end{array}$ & $\begin{array}{l}-0.164 * \\
(0.119)\end{array}$ \\
\hline & Observations & 2160 & 923 & 1697 & 854 \\
\hline & Controls & $\begin{array}{l}\text { Ethnicity, } \\
\text { Population }\end{array}$ & $\begin{array}{l}\text { Ethnicity, } \\
\text { Population }\end{array}$ & $\begin{array}{l}\text { District FE, } \\
\text { Population }\end{array}$ & $\begin{array}{l}\text { District FE, } \\
\text { Population }\end{array}$ \\
\hline
\end{tabular}

Note: All regressions include time effects. The coefficient on population is fixed to unity, in order to control for scale (using the Stata -exposure" option). Sample sizes vary as regions with no incidents during the entire sample period are excluded. Standard errors in parentheses. ${ }^{* * *} \mathrm{p}<.01,{ }^{* *} \mathrm{p}<.05, * \mathrm{p}<.1$, one-tailed with $\mathrm{H}_{0}: \beta>0$. Variables described in note to Table 1 . 
Supplemental Table S2: Unemployment and Violent Incidents in Afghanistan with Extra Controls

\begin{tabular}{|c|c|c|c|c|c|c|c|}
\hline Dependent Variable & $\mathrm{AGE} / 1000$ & AGE/1000 & JOISS/1000 & CIDNE/1000 & $\mathrm{AGE} / 1000$ & JOISS/1000 & CIDNE/1000 \\
\hline Unemployment & $\begin{array}{c}-0.049 * \\
(0.035)\end{array}$ & $\begin{array}{c}-0.050 * \\
(0.035)\end{array}$ & $\begin{array}{c}-0.066^{*} \\
(0.044)\end{array}$ & $\begin{array}{c}-0.051 * \\
(0.036)\end{array}$ & $\begin{array}{c}0.004 \\
(0.008)\end{array}$ & $\begin{array}{c}-0.004 \\
(0.012)\end{array}$ & $\begin{array}{c}0.006 \\
(0.008)\end{array}$ \\
\hline$\%$ Pashtun & & $\begin{array}{c}0.010 \\
(0.011)\end{array}$ & $\begin{array}{l}0.027 * \\
(0.017)\end{array}$ & $\begin{array}{c}0.011 \\
(0.011)\end{array}$ & $\begin{array}{l}0.047 * \\
(0.030)\end{array}$ & $\begin{array}{l}0.069 * \\
(0.039)\end{array}$ & $\begin{array}{l}0.049 * \\
(0.031)\end{array}$ \\
\hline$\%$ Pashtun x Unemp. & & & & & $-0.148 *$ & $\begin{array}{c}-0.170 * \\
(0.118)\end{array}$ & $\begin{array}{c}-0.155^{*} \\
(0.096)\end{array}$ \\
\hline$\%$ Male & & $\begin{array}{c}0.118 * * \\
(0.039)\end{array}$ & $\begin{array}{c}0.188 * * \\
(0.076)\end{array}$ & $\begin{array}{c}0.099 * * \\
(0.035)\end{array}$ & $\begin{array}{l}0.127 * * \\
(0.042)\end{array}$ & $\begin{array}{c}0.199 * * \\
(0.078)\end{array}$ & $0.108 * *$ \\
\hline$\%$ No Schooling & & $\begin{array}{c}0.004 \\
(0.011)\end{array}$ & $\begin{array}{l}-0.003 \\
(0.020)\end{array}$ & $\begin{array}{c}0.004 \\
(0.010)\end{array}$ & $\begin{array}{c}0.005 \\
(0.011)\end{array}$ & $\begin{array}{l}-0.002 \\
(0.020)\end{array}$ & $\begin{array}{c}0.005 \\
(0.010)\end{array}$ \\
\hline Avg. Household Size & & $\begin{array}{l}-0.003 \\
(0.002)\end{array}$ & $\begin{array}{c}-0.008 * * \\
(0.004)\end{array}$ & $\begin{array}{l}-0.004 \\
(0.003)\end{array}$ & $\begin{array}{l}-0.004 * \\
(0.002)\end{array}$ & $\begin{array}{c}-0.008 * * \\
(0.004)\end{array}$ & $\begin{array}{l}-0.004 * \\
(0.002)\end{array}$ \\
\hline District FE & - & Yes & Yes & Yes & Yes & Yes & Yes \\
\hline Observations & 2,146 & 2,146 & 2,146 & 2,146 & 2,146 & 2,146 & 2,146 \\
\hline R-squared & 0.081 & 0.092 & 0.123 & 0.083 & 0.108 & 0.133 & 0.101 \\
\hline
\end{tabular}

Note: All regressions include ANQAR wave fixed effects and are weighted by population. Robust standard errors clustered by district reported in parentheses. $* * * \mathrm{p}<.01, * * \mathrm{p}<.05, * \mathrm{p}<.1$, one-tailed test with $\mathrm{H}_{0}: \beta>0$. Variables described in note to Table 1 . Afghanistan has 363 districts included in the samples above. 


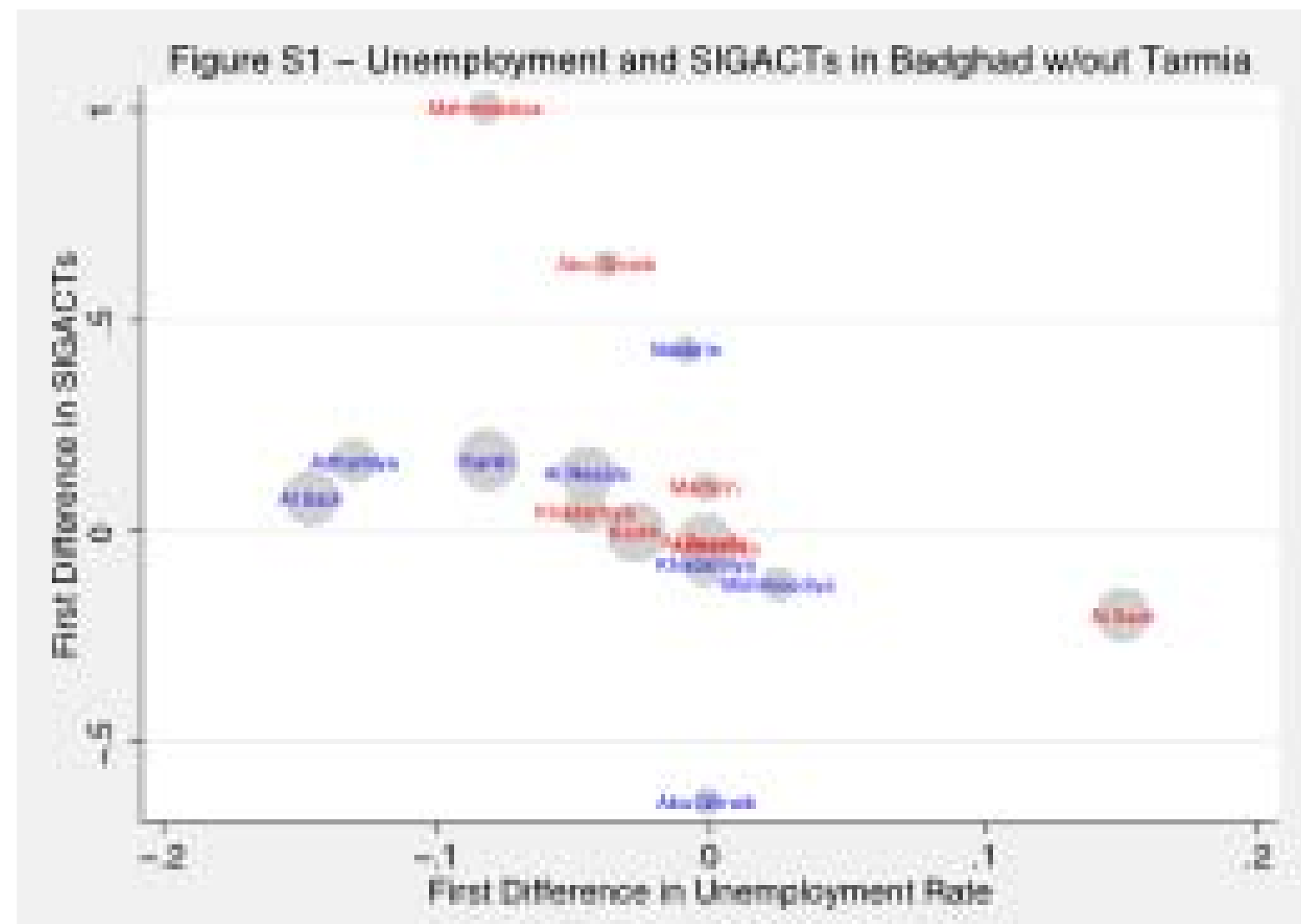

First differences: 04-05 (red), 05-07(blue) (Table 3, column 2) ${ }^{28}$

\footnotetext{
${ }^{28} 9$ districts x 3 years $=18$ observations of differences.
} 


\section{Appendix 1: Testing Joint Hypotheses About the Same Relationship With Potentially Correlated Coefficients}

This note is designed to clarify Figure 1 in "Do Working Men Rebel", which illustrates how the p-value (probability of rejecting when true) is related to a cross-sample correlation between estimated values of a given coefficient. The following is relevant only in the case where we are jointly testing hypotheses about the same relationship (i.e., comparable tstatistics) using different datasets.

There are two factors to consider in testing a joint hypothesis about the same relationship when coefficients may be correlated:

1. The higher the degree of correlation, the less information is provided by additional tests of the same hypothesis using additional datasets.

2. The higher the degree of correlation, the more relevant a t-statistic in one dataset is to our inference in another dataset.

The second factor is most relevant if our various datasets generate different t-statistics. To illustrate, in Figure 1 the t-statistic is equal to 1.96 in three hypothetical datasets. The yaxis depicts the $\mathrm{p}$-value of a joint test that the null hypothesis is true in all three populations, using a Chi-squared test, and the x-axis depicts the coefficient of correlation between the three tests. Because the t-statistics are identical, consideration 1 dominates. That is, increasing the correlation between the coefficients (and therefore the t-statistics), means that the additional tests yield less information. In the limit the additional tests yield no additional information, and we reject the null at $5 \%$ confidence just as we would if there were only one dataset.

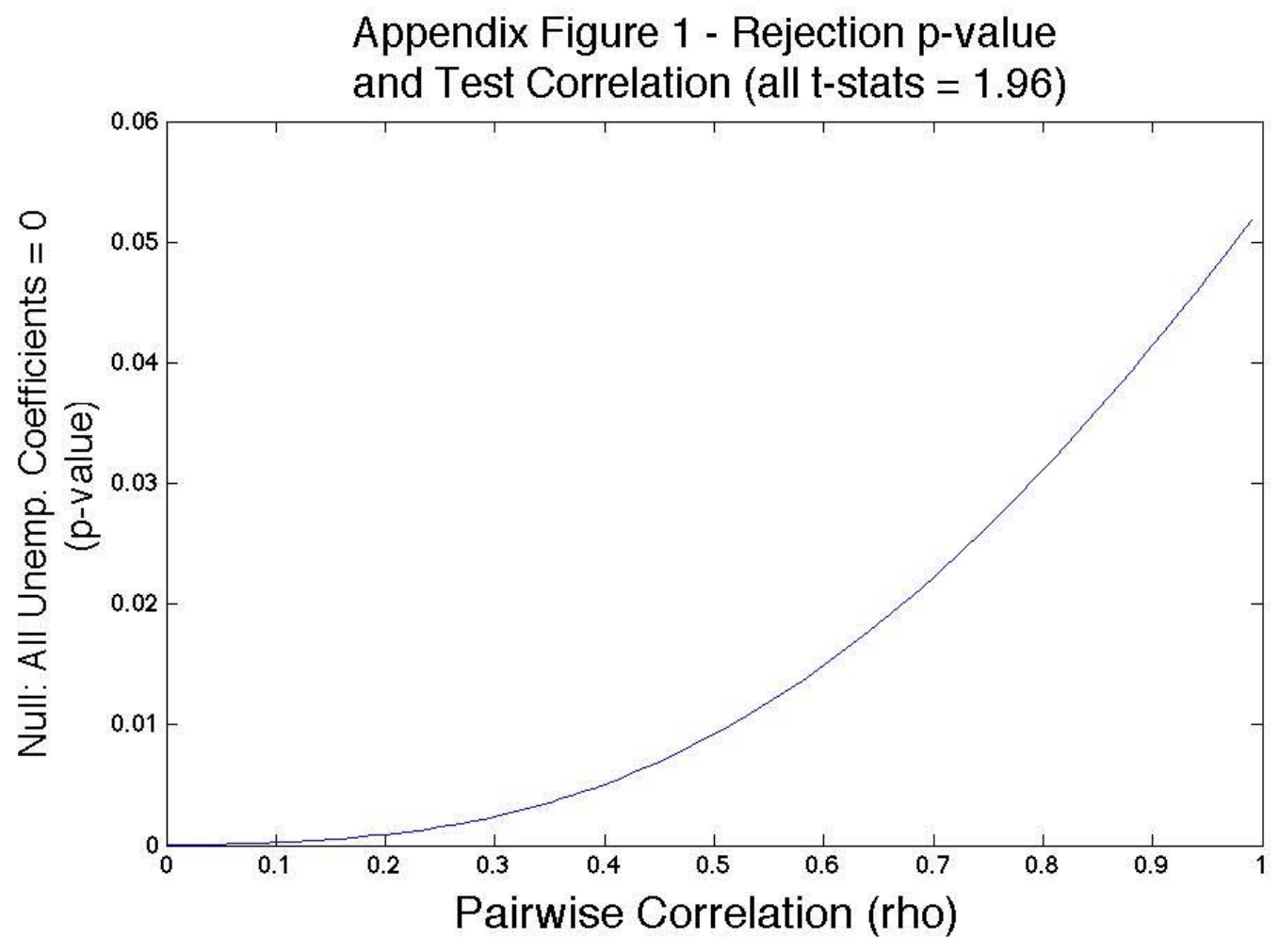


However, if we have different t-statistics in our different datasets, then a strong rejection in one dataset has spillovers for inference in the others. With a high degree of correlation, then, strong rejection in some dataset in the presence of weak rejection in others can combine to strenghten our confidence in rejecting the joint null hypothesis. To demonstrate, Figure 2 sets the t-statistic equal to 1.96 in two hypothetical datasets and equal to 1 in another.

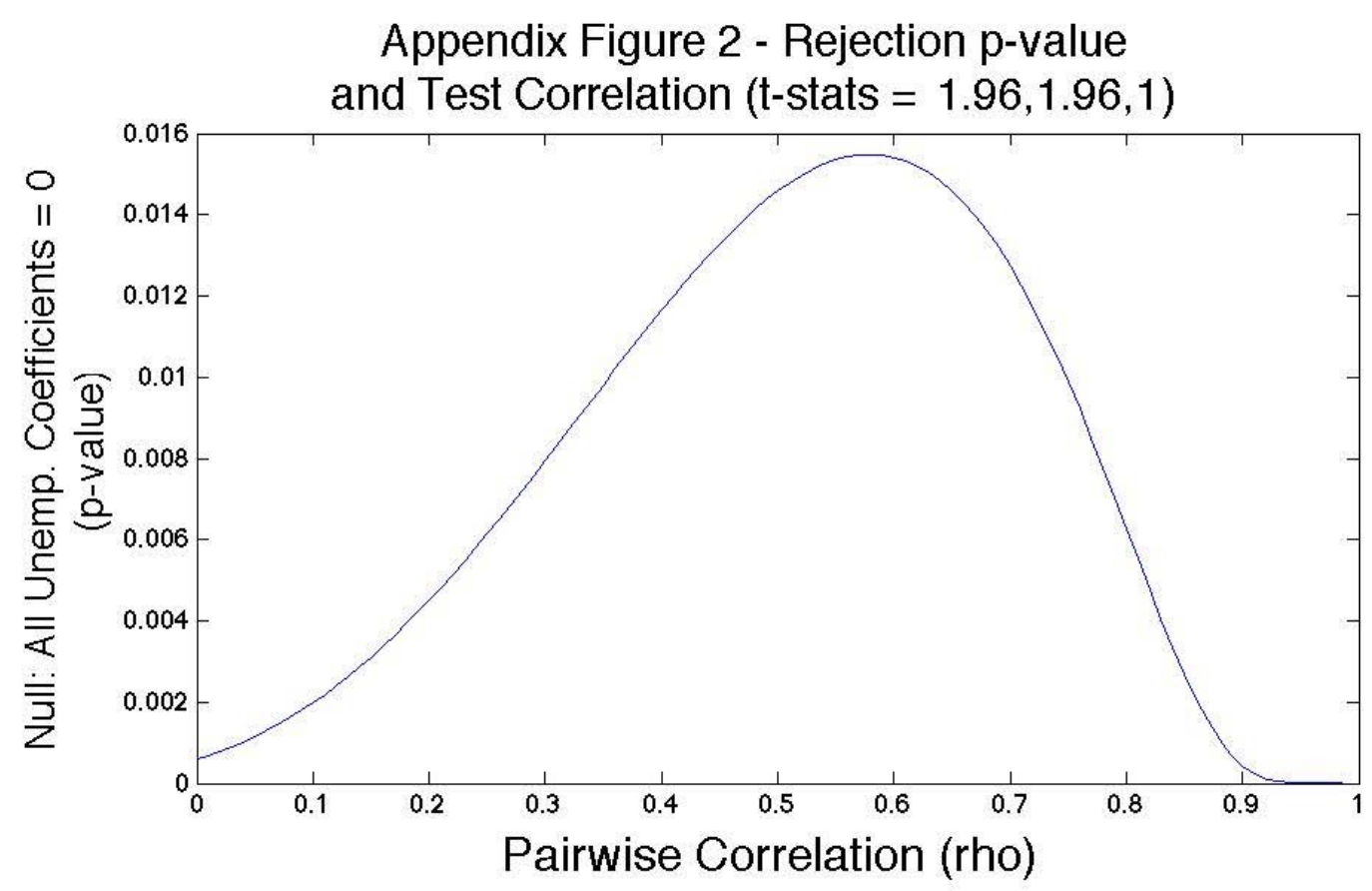


To reinforce this point, I have also simulated a joint test with a t-ratio of 1.96 in one dataset and 1 in two others. Here we see that strong rejection begins to dominate at a lower degree of correlation.

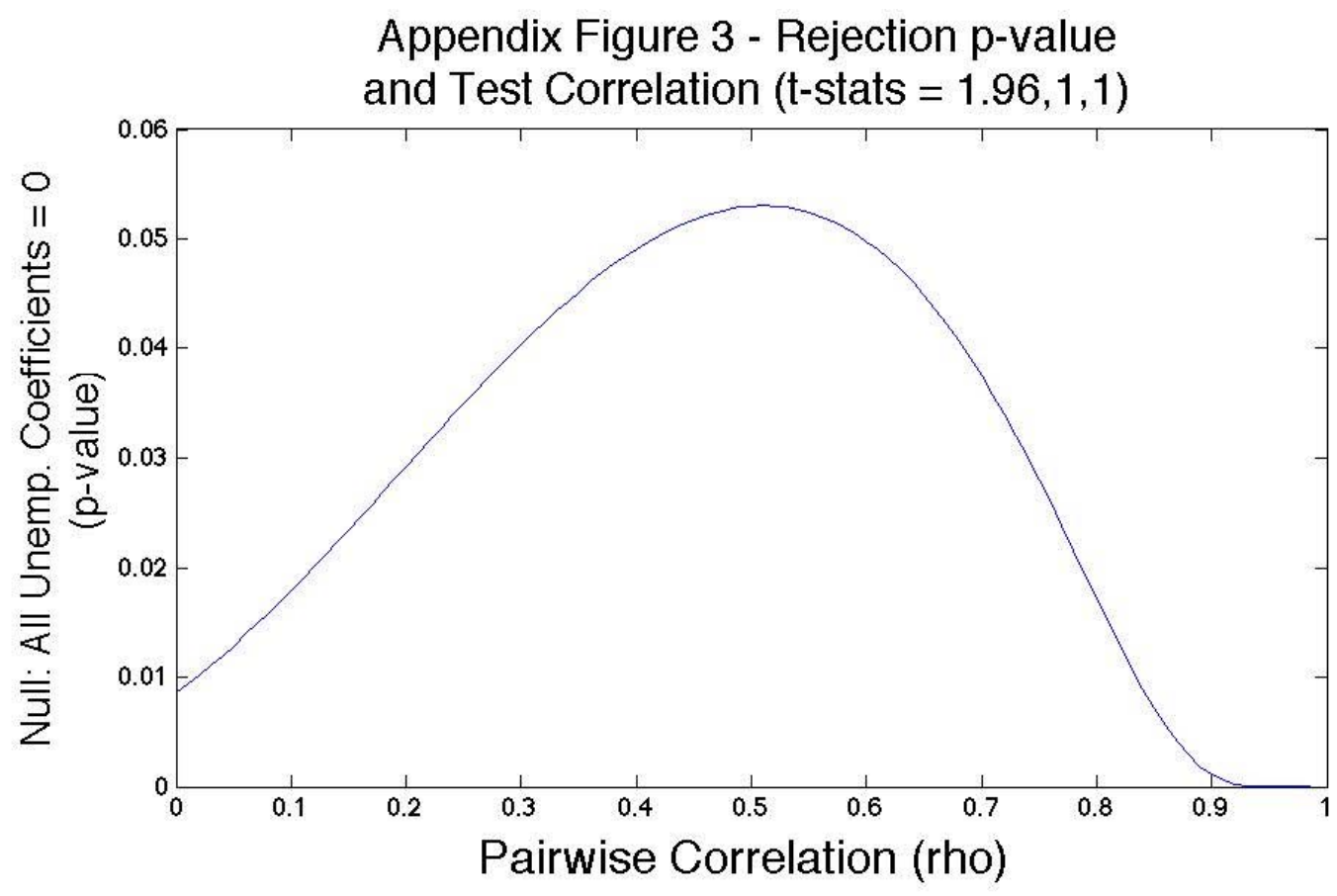

